\title{
El concepto de criminalidad organizada transnacional: problemas y propuestas*
}

\author{
LAURA ZÚNIIGA RodRÍGUeZ ${ }^{* *}$
}

\section{Resumen}

El presente trabajo se ahonda en la comprensión del concepto criminalidad organizada transnacional, dada la escasez de acuerdos sobre su contenido y su deficitaria regulación. Se trata de un concepto propio de la complejidad de la posmodernidad, por tanto presupone conceptos previos como criminalidad organizada. Además, dada su configuración más allá de las regulaciones particulares de los Estados y la necesidad de comprender comportamientos muy disímiles, se caracteriza por su fluidez y por límites no necesariamente ciertos. El hecho que coincide en la realidad social con otros fenómenos criminales complica aún más su determinación. No obstante, resulta necesario para plantear una Política Criminal común entre los Estados, unos acuerdos de mínimos. Me centraré en los problemas y propuestas sobre el carácter transnacional de los delitos cometidos por las organizaciones criminales internacionales.

\section{Palabras clave}

Criminalidad organizada. Criminalidad organizada transnacional. Delitos transnacionales. Delitos internacionales. Convención de Palermo.

\footnotetext{
* Este trabajo se inscribe en el Proyecto de Investigación DER2013-44228-R: "La criminalidad organizada transnacional: una amenaza para la seguridad de los Estados democráticos", financiado por el Ministerio de Economía y Competitividad.

** Profesora titular de Derecho Penal de la Universidad de Salamanca, catedrática acreditada. Izr@usal.es
} 


\section{Abstract}

This paper delves into the understanding of the transnational organized crime concept, given the lack of agreement on its content and deficiency of regulation. It is a typical concept of the complexity of postmodernism; therefore it presupposes previous concepts such as organized crime. Given its configuration beyond the regulations from particular States and the need to understand very different behaviors, it is characterized by its fluidity and not necessarily certain limits. Its determination is even more complicated because the social reality coincides with other criminal phenomena. However, it is necessary some minimal agreements to raise a common criminal policy among states. I will focus on the problems and proposals the transnational nature of the crimes committed by international criminal organizations.

\section{Key words}

Organized crime. Transnational organized crime. Transnational crimes. International crimes. Palermo Convention.

\section{Sumario}

1. Introducción; 2. El punto de partida: el significado de la Convención de Naciones Unidas contra la Criminalidad Organizada Transnacional de 2000; 3. La regulación española sobre la materia: ¿Qué se ha traspuesto de la Convención de Palermo?; 4. Distinción entre delitos transnacionales y delitos internacionales; 5 . Una propuesta de mínimos: criminalidad organizada transnacional / delito transnacional; 5.1. La complejidad: el todo y las partes; 5.2 . De las nociones criminológicas a las nociones jurídicas; 5.3. Naciones Unidas y la Convención de Palermo; 5.4. La Unión Europea y la Decisión Marco de 2008; 5.5. ¿Qué se entiende por delitos graves? La gravedad de la criminalidad organizada transnacional; 5.6. ¿Qué delitos específicos pueden ser propios de la criminalidad organizada transnacional?; 5.7. La gravedad de la criminalidad organizada transnacional (la lesividad de la organización criminal de carácter internacional); 5.8. Participación en organización criminal, responsabilidad penal de las personas jurídicas, non bis in ídem y garantías; 6 . Conclusiones: Conjugando el todo y las partes: el significado de criminalidad organizada transnacional. 


\section{Introducción}

La superación de las barreras de los territorios nacionales por parte de la criminalidad organizada es un hecho empíricamente constatable que no se aviene bien con un derecho penal anclado en cánones propios del surgimiento de los Estados nacionales del siglo XVIII, en los que la legitimidad de los mismos se explicaba para dar seguridad a los propios ciudadanos frente a los "enemigos externos" y, por tanto, cada Estado poseía la soberanía para decidir qué castigar, cómo castigar y a quién castigar. La territorialidad de la ley penal y el monopolio del ius puniendi se explicaban así, como corolario de un sistema de pensamiento en el que cada Estado "mira hacia adentro", organizando y gestionando su propio territorio, con miras a que el otro Estado haga lo suyo. Asimismo, los Estados se presentaban como fortalezas cerradas, protegidas por el principio de no injerencia'.

Estos acuerdos propios de la era de la Modernidad², se han ido derrumbando por la dinámica de la interdependencia de los Estados, la fluidez de los medios de comunicación, la movilidad de los flujos económicos y migratorios, en suma, por lo que hoy denominamos globalización. La capacidad de los Estados para hacer frente a los diversos tráficos ilícitos de bienes, personas y servicios, en los que la oferta y la demanda se producen de un país a otro, con los instrumentos nacionales diseñados a partir de principios decimonónicos construidos bajo el prisma del Estado nacional y su consiguiente monopolio de la ley penal, deviene obsoleta, trasnochada y fuertemente menguada, porque en realidad se trata de otro paradigma, otra fenomenología de actuación de las organizaciones criminales actuales que, en muchos casos, difícilmente encaja en las nociones tradicionales.

Esta última ola de la globalización, de marcado tinte neoliberal, nos ha conducido a un mundo desregularizado, especialmente del comercio y de los mercados financieros, con consecuencias en todos los ámbitos de la vida social de los individuos, pues los antiguos Estados nacionales ya no otorgan esas viejas seguridades, porque han cedido sus capacidades de regulación, organización y gestión en pos de empresas transnacionales, organismos financieros, y en el mejor de los casos, de organismos supranacionales, quienes son los que realmente dictan

1 Vid. más ampliamente sobre la crisis de la soberanía nacional o, más bien, "la transformación de la soberanía", Zagrebelsky, G., El Derecho dúctil. Ley, derechos, justicia, Madrid, Trotta, 2011, 10ª ed, págs. $10-12$.

2 Como recuerda Innerarity, D., Un mundo de todos y de nadie. Piratas, riesgos y redes en el nuevo desorden global, Barcelona, Paidós, 2013, pág. 18: la noción de "territorio" fijo y delimitado es una creación de la modernidad. "La modernidad se inaugura epistemológicamente como una supremacía de la fijación territorial frente a la fluidez y ambigüedad del líquido marino". 
buena parte de las leyes. Ahora bien, precisamente el último reducto de ese Estadonación que se resiste a desaparecer es la vigencia de la ley penal en el territorio nacional. El derecho penal nacional se presenta como la fortaleza de las fronteras trazadas en el surgimiento de los Estados-nación. Se puede afirmar que constituye un "muro"3 simbólico que aquieta las ansiedades de seguridad de los ciudadanos y mantiene la mitología de la existencia de un Estado. Ahora bien, es puramente simbólico porque la realidad tozuda nos muestra la imposibilidad de mantener esos mitos.

Particularmente evidente de esta realidad "líquida" de las fronteras es el ciberespacio, donde se pueden perpetrar innumerables delitos trascendiendo los límites legales y territoriales de los Estados. La llamada cibercriminalidad (computer crime) en expansión con el desarrollo y universalización de internet por el orbe, es el espacio idóneo para realizar conductas delictivas amparadas por el anonimato, la ubicuidad y, sobre todo, por tratarse de un ámbito prácticamente desregulado en la medida que no pueden ser objeto de leyes nacionales. Los delincuentes en red son capaces de realizar conductas que en solitario no tendrían posibilidad, como la pornografía infantil, entre otros. Pero sobre todo, el ciberespacio aunado a la desregulación financiera de los últimos años han facilitado el blanqueo de las ganancias ilícitas, dando fuelle a la criminalidad organizada, en la medida que el simple movimiento de capitales puede blanquear el dinero ilícitamente obtenido 4 . Así el blanqueo de capitales, conjuntamente con el fraude tributario ${ }^{5}$, se convierten en los ilícitos donde confluyen las diversas formas de criminalidad transnacional. El principio de territorialidad de la ley penal ha sido un principio básico de funcionamiento de las competencias de las jurisdicciones nacionales y de afirmación

3 InNerarity, Un mundo de todos y de nadie, cit., pone en evidencia la construcción frenética de muros en la última década: entre México y Estados Unidos, Israel y Palestina, España y Marruecos, India y Pakistán, etc., etc., ... "solo entre Estados Unidos, India e Israel se han construido un total de 5.700 kilómetros de barreras de seguridad", pág. 76. Asimismo, resalta que este "amurallamiento" de la modernidad tardía es el síntoma del debilitamiento de la soberanía estatal; no indican el fortalecimiento del Estado-nación, sino que son realmente iconos de su erosión, pág. 77.

4 Gutiérrez Francés, M., "Las altas tecnologías de la información al servicio del blanqueo de capitales transnacionales", Aquilafuente, №38, pág. 209, quien nos muestra que la manipulación informática es precisamente el medio idóneo para "tejer una complicada red de operaciones entrecruzadas y sinuosos canales muy difíciles de investigar".

5 A partir de la "lista Falciani" de miles de defraudadores tributarios, se ha descubierto que el propio banco HSBC asesoraba en la creación y control de sociedades pantalla en paraísos fiscales Vid. El País, 11 de febrero de 2015. Cfr. Ferré Olivé, J.C., "Una nueva trilogía en Derecho penal tributario: fraude, regularización y blanqueo de capitales", en Revista de contabilidad y tributación, № 372 , 2014, págs. 44 y ss., donde el autor trata de los problemas jurídico-penals generados por el Real Decreto 12/2012, de 30 de marzo, de regularización fiscal extraordinaria. 
del monopolio de la ley. Los otros principios de aplicación de la ley en el espacio que se conocen, principio de personalidad, principio real o de defensa, principio de justicia universal, en realidad constituyen excepciones a ese dogma. El principio de legalidad, también fundamental en la epistemología penal, cierra el círculo de esta fuerza contraria a superar el principio de territorialidad, en la medida que es necesario definir claramente las conductas delictivas y esto sólo se puede hacer de acuerdo a realidades concretas, a realidades nacionales.

En este sistema de fuentes desregulado, la gobernanza global presenta en su agenda algunos "apremios universalistas" para el derecho presente ${ }^{6}$ : la lucha contra el terrorismo y contra la criminalidad organizada transnacional, la protección frente al deterioro del medio ambiente, la proliferación de armas nucleares, la lucha contra los paraísos fiscales y el secreto bancario, como los más acuciantes. Siendo evidente que en todos estos casos sólo es posible una verdadera protección cuando se efectúe a nivel internacional. La importancia de estos temas para la seguridad de los Estados ha sido puesta en evidencia reiteradamente por Naciones Unidas. En el año 2005, el entonces Secretario General de la ONU, Koffi Anan, en su informe Un concepto más amplio de libertad: desarrollo, seguridad y derechos humanos para todos ${ }^{7}$, mostraba que terminada la Guerra Fría y cuando parecía haberse iniciado una era de paz, las preocupaciones en torno a la seguridad vuelven a dominar la agenda internacional, esta vez de la mano de grupos criminales diversos que se interconectan fácilmente y aumentan su potencia criminal. En el punto 78 sostiene: "Entre las amenazas a la paz y la seguridad en el siglo XXI se cuentan no sólo la guerra y los conflictos internacionales, sino los disturbios civiles, la delincuencia organizada, el terrorismo y las armas de destrucción en masa ... Todas ellas pueden socavar a los Estados como unidades básicas del sistema internacional".

Indudablemente nos encontramos ante un serio problema: una fenomenología criminal que trasciende las fronteras de los Estados nacionales con cada vez más capacidad para hacer frente a los mismos y de incrementar sus ganancias ilícitas y, de otro lado, una ley penal que está creada y aplicada dentro de las frágiles fronteras de los territorios nacionales.

El presente trabajo se ahonda en la comprensión del concepto criminalidad organizada transnacional, dada la escasez de acuerdos sobre su contenido, sobre sus límites y, en suma, su regulación jurídica. Desde ya debo decir que se trata de

6 En palabras de Pérez Luño, A., El desbordamiento de las fuentes del Derecho, Madrid, La Ley, 2011, pág. 96.

7 Informe A/59/2005, de 21 de marzo de 2005, correspondiente al Quincuagésimo noveno período de sesiones, Temas 45 y 55 del programa, Aplicación y seguimiento integrados y coordinados de los resultados de las grandes conferencias y cumbres de las Naciones Unidas en las esferas económica y social y esferas conexas, Seguimiento de los resultados de la Cumbre del Milenio. 
conceptos propios de la complejidad de la posmodernidad, puesto que presupone conceptos previos, al menos el de criminalidad organizada, los mismos que no siempre encuentran tampoco fáciles acuerdos. Se tratará por tanto de un concepto fluido, con límites no necesariamente ciertos $^{8}$, pero que en todo caso, sea funcional para un mejor abordaje jurídico y político-criminal. Teniendo en cuenta que se ha comprobado la imposibilidad de la ciencia jurídica de establecer conceptos inmutables, dado el vertiginoso avance de los hechos sociales que, en este ámbito, es especialmente dinámico ${ }^{9}$.

En suma, intentaré responder a la pregunta ¿Qué criterios deben considerarse necesarios para comprender la criminalidad organizada transnacional? Como sostiene Boister, la taxonomía debe tener un propósito: identificar un Derecho Penal Transnacional nos ayuda a saber cómo se utiliza la ley internacional para suprimir social, económica y moralmente conductas indeseables inter e intra estatales ${ }^{10}$. Pero para ello, para realizar una cooperación internacional entre los Estados es preciso acercar los ordenamientos jurídicos (armonizar), esto es, poseer un soporte jurídico común 0, al menos, cercano ${ }^{11}$.

Como dice Innerarity, "el mundo se ha vuelto más complejo y no terminamos de estar a la altura de esa complejidad"12. Pero la necesidad de hacer frente a esa agenda de riesgos globales, nos impulsa a plantear al menos un acuerdo de mínimos. Lo contrario es la inseguridad jurídica, el caos normativo y, por tanto, una válvula de oxígeno para estas formas de criminalidad.

8 Zagrebelsky, G., El derecho dúctil. Ley, derechos, justicia, Madrid, Trotta, 2003, 5ª ed., pág. 17 nos advierte de una "dogmática fluida": "debe ser como el líquido donde las sustancias que se vierten -los conceptos- mantienen su individualidad y coexisten sin choques destructivos". La idea de la fluidez en la posmodernidad es del sociólogo Zigmunt Bauman, "la sociedad líquida".

9 Cfr. Mııtello, V., "L'identità della scienza giuridica penale nell'ordinamento multilivello", en Rivista italiana di Diritto e procedure penale, Fascículo 1, 2014, pág. 116, quien precisamente pone en cuestión una foto fija de la ciencia penal, para subrayar su dinamismo, en la medida que está a remolque de la realidad social siempre cambiante.

10 Boister, N. "Transnational criminal law?", European Journal of International Law, Vol. 14, No. 5, 2003 pág. 956.

11 Por ejemplo, si nos referimos al blanqueo de capitales desde un punto de vista del Derecho Comparado, se observa desde la inexistencia de tipificaciones penales, a tipos penales restrictivos, limitados a la configuración del mismo referente a bienes habidos del tráfico de drogas. Como afirma GutiérRez Francés, "Las altas tecnologías de la información al servicio del blanqueo de capitales transnacionales", cit., pág. 205: "si circunscribimos el estudio estrictamente a la dimensión jurídicopositiva, la principal limitación en el diseño del delito de blanqueo de capitales allí donde se tipifica esta figura, no deriva de una restricción inaceptable de los medios comisivos (que pudiera dejar fuera el blanqueo de bienes mediante manipulaciones informáticas subrepticias), sino de su concreción positiva como delito necesariamente conexo al narcotráfico".

12 Innerarity, Un mundo de todos y de nadie, cit., págs. 60-61. 
Aún centrando el análisis al concepto de criminalidad organizada transnacional, existen varios aspectos que no pueden ser abordados en un solo trabajo. En primer lugar, no me ocuparé de una clasificación más amplia que sería el delito transnacional, pues este concepto abarca el terrorismo ${ }^{13}$, sino de los diversos tráficos ilícitos que trascienden los Estados. Además, la transnacionalidad de las conductas ilícitas poseen diversas vertientes, a saber:

1. La transnacionalidad de la conducta delictiva.

2. La transnacionalidad de las ofensas.

3. La transnacionalidad de los productos delictivos.

4. La transnacionalidad de la cooperación policial.

5. La transnacionalidad de la cooperación judicial.

6. La transnacionalidad probatoria.

7. La transnacionalidad de la ejecución de sentencias.

Realmente los que corresponden al presente análisis son los dos primeros supuestos, siendo los siguientes importantísimos para una adecuada Política Criminal integral contra este fenómeno criminal ${ }^{14}$, pero escapan a los objetivos de este trabajo, a los que sin embargo se hará alusión puntualmente.

\section{El punto de partida: el significado de la Convención de Naciones Unidas contra la Criminalidad organizada transnacional de 2000}

El nuevo siglo se inauguró con un acuerdo importante sobre la materia que nos ocupa. Sin duda la conocida como Convención de Palermo de 2000 y denominada formalmente "Convención contra la Criminalidad organizada transnacional", constituye un hito histórico de consenso sobre esta moderna criminalidad que se hace cada vez más patente en la era de la globalización. El acuerdo multilateral que supone establecer definiciones comunes para los Estados nacionales sobre conceptos cuya realidad criminológica es compleja, proteica, plagada de especificidades, sólo puede saludarse bajo el prisma de la necesidad de la cooperación internacional y la

13 Dando por hecho que existen elementos comunes, como las organizaciones criminales, tanto la Política Criminal, como el tratamiento jurídico nacional e internacional los distinguen.

14 Siendo todos importantes, destaco la relevancia de la cooperación internacional en la recuperación de activos, especialmente del comiso de las ganancias ilícitas. Se trata de la transnacionalidad de los productos del delito que, según los estudios últimos, deben centrar la atención de los operadores jurídicos, para "extrangular" la financiación de las organizaciones criminales. Vid. Aguado, T., "Decomiso de los productos del delito en la delincuencia organizada, Garantizar que el delito no resulte provechoso", Revista electrónica de Ciencia Penal y Criminología, № 15-05, 2013, passim. 
armonización de las legislaciones, frente a la grave amenaza que las diversas formas de criminalidad organizada transnacional representan para la seguridad, la paz y el desarrollo democrático de los Estados.

Por supuesto que no todos los Estados se encuentran en la misma situación de amenaza frente a la criminalidad organizada transnacional, pues existen diversas realidades nacionales con especificidades muy particulares. De ahí también la dificultad de llegar a acuerdos internacionales, toda vez que algunos países no perciben, o no de la misma magnitud que otros, la amenaza de la criminalidad organizada transnacional. Incluso, en muchos casos, los propios Estados se representan diversas formas de criminalidad cuando se refieren al crimen organizado.

Por eso alcanzar acuerdos en esta materia, teniendo en cuenta realidades y legislaciones muy diferentes, conciliando las tradiciones jurídicas del common law y el sistema eurocontinental, no puede ser más que encomiable. El camino para llegar a la Convención de Palermo fue un proceso largo y difícil que conviene no olvidar, pues explican muchas de las cuestiones a debate. Entre otras, la influencia de la noción de conspiracy de los anglosajones, impropia de nuestra tradición jurídicopenal que fundamenta el delito en al menos el comienzo de la tentativa, es decir, en la lesividad de la conducta. El carácter conspirativo del crimen organizado, especialmente desarrollado en los Estados Unidos de América de los años cincuenta $^{15}$, es una consecuencia de la capacidad de leyenda que posee esta forma de criminalidad, fomentada por algunos sectores de la sociedad norteamericana, ha sido idónea para justificar políticas criminales de "enemigos". En todo caso, esta representación de la criminalidad organizada, exportada por el cine norteamericano principalmente, ha denotado un tipo de criminalidad de "los otros", representativa de todos los males y con capacidad de dañar las estructuras del Estado, una criminalidad cuasi-política, que se pone enfrente de las instituciones estatales, "outside the control of the American people and their governments" ${ }^{16}$, olvidando que los estudios criminológicos demuestran, más bien, que se trata de una criminalidad que fluye en las estructuras económicas y sociales en los Estados contemporáneos. Esa visión del crimen organizado como "enemigo", ha sido una constante en los

15 El Comité dirigido por el senador Kefauver en 1950 y 1951, sugirió que la Mafia era una conspiración de italianos, contra la "respetable sociedad" norteamericana. La Mafia se erigía así como una amenaza contra el sistema político, económico y legal de América, Cfr. Woodiwiss, M., "Transnational organized crime. The global reach of an American concept", en Edwards /GILL, Transnational Organized Crime. Perspectives on global security, Nueva York / Oxon, Routledge, 2003, pág. 15.

16 Así definía la "organized crime" el Presidente de la Comisión Jhonson, en 1967. Cfr. Woodiwiss, "Transnational organized crime. The global reach of an American concept", cit., pág. 16. 
Estados Unidos y ha influenciado fuertemente los convenios internacionales sobre el tema, especialmente, los vinculados al tráfico de drogas, blanqueo de dinero y corrupción ${ }^{17}$.

La primera vez que Naciones Unidas se ocupa de este fenómeno y, por tanto, reconoce su existencia y su dañosidad social es en 1975, en el seno de la V Convención de Naciones Unidas para la Prevención del Crimen, en el cual se examinó "Cambios de las formas y dimensión de la delincuencia transnacional y nacional". En esa misma Convención se reconoció la importancia de la criminalidad como empresa (crime as business), señalando los diversos niveles de la misma: criminalidad organizada, criminalidad de empresa (white-collar crime) y corrupción. La criminalidad como empresa fue reconocida como un problema más serio para la sociedad y las economías nacionales que la delincuencia tradicional, especialmente para los países en vías de desarrollo $0^{18}$. Sin duda aquí se puede ver la impronta de la Ley R.I.C. $0^{19}$. que es la primera regulación a nivel mundial que da nombre y carta de naturaleza al crimen organizado.

Seguidamente diversas convenciones de NN UU se ocuparon del tema, ya sea en relación al terrorismo, la corrupción o la delincuencia transnacional. Pero ha sido en 1994 cuando NN UU logra el mayor consenso internacional al respecto, al reunir a representantes de 142 Estados en Nápoles (Italia), los días 21-23 de noviembre, para aprobar la Declaración Política y Plan de Acción Global contra la Criminalidad Organizada Transnacional, que fue más tarde aprobada por la Asamblea General de Naciones Unidas (Resolución 49/159 de 23 de diciembre de 1994). Lo especialmente interesante de esta Convención es el interés por establecer definiciones comunes de aspectos clave: grupo criminal organizado, delito grave, delitos transnacionales, etc., en un mundo, como se ha dicho, plagado de diferencias.

17 Sobre la influencia de esta política criminal de combate de los Estados Unidos en la Política Criminal europea Vid. Vogel J., en Revista Penal, No 11, 2003, "Política criminal y dogmática penal europeas", ob. cit., pág. 141, quien resalta que en el proceso de interlegalidad europeo, se observa la americanización del Derecho Penal, "el más influyente del mundo" (sic).

18 Cfr. Bassiouni / Vetere, Organized Crime. A Compilation of U. N. Documents 1975-1998, New York, ONU, 1998, cit., pág. XVII y Vid. un extracto del documento en, el mismo, págs. 812-815. Sobre estos aspectos internacionales de Naciones Unidas se sigue básicamente este texto.

19 La señal de inicio de la noción internacional de criminalidad organizada lo marca la ley estadounidense Organized Crime Control Act de 1970, comprendida en la más notoria Racketeer Influenced and Corrupt Organizations (Ley sobre las organizaciones corruptas y extorsionadoras, mundialmente conocida como ley R.I.C.O.), que propone una visión relativamente más genérica del fenómeno en examen, poniendo de relieve el carácter organizativo y corruptivo del mismo, y renunciando a construir una definición más articulada y descriptiva de la complejidad del fenómeno que lo comprende. La Ley RICO tipifica el delito de participación en los asuntos de una empresa con ayuda de métodos extorsivos, con lo cual se vincula la noción de criminalidad organizada con la criminalidad de empresa. 
La gobernanza de la lucha contra la criminalidad organizada transnacional parece uno de los temas en los que se requieren instituciones internacionales consensuadas por todos los actores mundiales ${ }^{20}$. Es decir, más que soluciones desreguladoras que resultan funcionales a la criminalidad organizada, es imprescindible plantear respuestas globales ante problemas planetarios y el crimen organizado es uno de ellos. Buscar la sinergia en la coordinación policial y judicial, intentar hablar un lenguaje común con la armonización de las legislaciones penales y procesales, facilitar el reconocimiento internacional de las diligencias de detención y extradición de los detenidos y condenados, no dejar paraísos legales ni fiscales, parecen urgentes medidas por las que hay que trabajar. Como sostiene David Held, Profesor de Ciencia Política en la London Schools of Economics and Political Sciences, la estrategia al fomento del intergubernamentalismo y de acciones interestatales para abordar problemas como las redes delictivas internacionales, comprende tres dimensiones interrelacionadas ${ }^{21}$ :

a) Fomentar una acción coordinada por parte del Estado con el fin de tratar problemas comunes;

b) Reforzar las instituciones internacionales que pueden funcionar con eficiencia;

c) Desarrollar normas y procedimientos multilaterales que engloben a todos los poderes, pequeños y grandes, en un marco multilateral.

La importancia de un instrumento internacional propiciado por Naciones Unidas, como la Convención de Palermo, queda patente por constituir una base mínima común, para agilizar la cooperación internacional. De ahí también la relevancia de que los Estados nacionales traspongan en sus legislaciones penales (armonización legislativa) los conceptos allí desarrollados, a los efectos de hacer realidad la mayor eficacia de prevención y represión de la criminalidad organizada transnacional. Las carencias en alguno de estos aspectos aboca al propio Estado a la posibilidad de convertirse en un "paraíso legal" para las mafias, con el consiguiente deterioro de

20 Precisamente el debate sobre la gobernanza de la globalización se sitúa en el reconocimiento de instituciones internacionales que establezcan parámetros válidos de legitimidad. Ante el vacío de poder dejado por la desregulación económica y política, se impone la reformulación de instituciones internacionales valedoras de los derechos fundamentales, como Naciones Unidas, en pos del redimensionamiento, sobre nuevas bases, del Derecho Internacional. Cfr. Mercado, P., "El proceso de globalización, el Estado y el Derecho, Portula (Dir.), Mutaciones del Leviatan. Legitimación de los nuevos modelos penales, Madrid, Akal, 2005, pág. 155. Se trata, de potenciar un "nuevo garantismo", un nuevo "Constitucionalismo mundial" como plantea Ferrajoul, L., Derechos y garantías. La ley del más débil, Madrid, Trotta, 1999, págs. 116 y ss. También HeLD, D., Un pacto global. La alternativa socialdemócrata al consenso de Washington, Madrid, Taurus, 2005, págs. 129 y s. También INNERARITY, Un mundo de todos y de nadie, cit., pág. 11: "no hay otra solución ante los miedos globales que avanzar hacia una desnacionalización de la justicia y una gobernanza global".

21 Cfr. Held, Un pacto global, cit., págs. 138-139. 
sus relaciones sociales, económicas y políticas. A tal punto, que puede poner en el peor de los casos, en jaque a las propias instituciones democráticas.

Hay que tener en cuenta que con anterioridad a la Convención de Palermo, las formas de colaboración eran bilaterales, en el mejor de los casos multilaterales por bloques económicos/ políticos. En cambio, dicha Convención constituye el punto de arranque para visibilizar la relevancia de un mínimo común denominador para cooperar más fluidamente entre los operadores jurídicos de los diversos Estados, en un mundo donde el trámite engorroso de la extradición queda totalmente trasnochado.

\section{La regulación española sobre la materia: ¿Qué se ha traspuesto de la Convención de Palermo?}

Aunque la Convención de Palermo es un instrumento de base para luchar globalmente contra un fenómeno global al que los Estados deben dar buena cuenta ineludiblemente, en la medida que se trata de compromisos de los Estados cuando lo han ratificado, como es el caso de España, lo cierto es que no se ha regulado específicamente el crimen organizado transnacional. No existe, como en Italia, la Ley No 146 de 16 de marzo de 2006, una ley que trasponga qué se entiende por delito transnacional. Sí se han traspuesto las nociones de "grupo delictivo organizado" y "grupo estructurado" en la LO 5/2010 que introduce en el CP los artículos 570 bis y 570 ter, donde se regulan ambos respectivamente como organización criminal y grupo criminal. Es lo más que se ha regulado en la legislación española sobre los acuerdos de la Convención de Palermo.

Como se sabe, el CP español tampoco contempla alguna norma sobre dónde se entiende cometido el delito. Es más bien creación jurisprudencial la determinación de la competencia española de conductas delictivas que se inician en España y producen resultados en otro Estado y viceversa, siguiendo la teoría de la ubicuidad. El principio de territorialidad de la ley penal se desprende del art. 8.1 código civil, conforme al cual "las leyes penales, las de policía y las de seguridad obligan a todos los que se hallen en territorio español". Asimismo, el art. 23.1 de la Ley Orgánica del Poder Judicial establece que corresponderá a la jurisdicción española el conocimiento de las causas por delitos y faltas cometidos en el territorio español" (locus regit actum).

Más bien dentro de la jurisdicción universal, impropiamente ${ }^{22}$, sí se regulan algunas conductas que corresponden a la criminalidad transnacional, como la piratería, el terrorismo, la trata de personas, el tráfico de drogas, delitos contra los

22 Pues como se verá en el epígrafe siguiente, no se debe confundir delitos internacionales y delitos transnacionales. 
ciudadanos extranjeros, delitos contra la seguridad del tráfico marino (art. 23.4 de la Ley Orgánica del Poder Judicial), siendo precisamente la impunidad del tratamiento del tráfico de drogas internacional, especialmente los casos de capturas en alta mar que, por los innumerables condicionantes que ha establecido la última reforma, no queda clara la capacidad de la jurisdicción española para su persecución ${ }^{23}$, lo que ha hecho saltar las alarmas sobre las restricciones de esta jurisdicción realizada por los dos últimos gobiernos.

Nos encontramos con reglas dispersas en el código penal que hacen referencia al carácter transnacional del delito y que agravan la pena cuando se trata de delitos cometidos por redes internacionales, como el supuesto de tráfico de drogas del art. $370 \mathrm{CP}$ 0, a lo más, contempla la reincidencia internacional en algunos supuestos, como en los delitos de trata de seres humanos del art. 177 bis 10, delitos contra la libertad e indemnidad sexuales del art. $190 \mathrm{CP}$, delitos de tráfico de drogas del art. $375 \mathrm{CP}$, delito de falsificación de moneda del art. $388 \mathrm{CP}$, delitos de terrorismo cometidos en el ámbito de organizaciones del art. 580 CP.

Lo que sucede en nuestra legislación penal es que reforma tras reforma se han ido incorporando tipos penales nuevos, agravaciones de nuevo cuño, sin una sistemática coherente, lo cual ha dado lugar a problemas aplicativos importantes, concursos de normas, de difícil solución y que da lugar a una merma de la seguridad jurídica ${ }^{24}$, tan relevante en un ámbito donde lo deseable es un mensaje preventivo claro a las organizaciones criminales internacionales ${ }^{25}$.

23 Después de varios supuestos en que la Audiencia Nacional resolvió la falta de capacidad de la jurisdicción española para perseguir los supuestos de tráfico de drogas perpetrados en altamar, porque dicha norma establece como requisito: $1 .{ }^{\circ}$ el procedimiento se dirija contra un español; $0,2 .{ }^{\circ}$ cuando se trate de la realización de actos de ejecución de uno de estos delitos o de constitución de un grupo u organización criminal con miras a su comisión en territorio español y, al no estar probado que el tráfico esté destinado a territorio español, la STS N $592 / 2014$, de 24 de julio, resuelve que en los casos de delitos de tráfico ilegal de drogas tóxicas, estupefacientes y sustancias psicotrópicas, cometidos en medios marinos, el apartado d) del art. 23.4 de la LOPJ confiere jurisdicción a las autoridades españolas para el abordaje, inspección, incautación de sustancias y detención de los tripulantes de cualquier embarcación que enarbole el pabellón de otro Estado, siempre que obtenga la autorización del Estado de abanderamiento del barco. Esta competencia supone la del enjuiciamiento de los imputados en caso de que se trate de buques sin pabellón, o resultando éste ficticio. Concluye el Tribunal que cuando se trate de naves con pabellón legítimo la competencia para el enjuiciamiento será la del país de bandera de forma preferente, y solamente de forma subsidiaria la del país que llevó a cabo el abordaje y la inspección.

24 Cfr. Méndez Rodríguez, C., "Los delitos de pertenencia a organización criminal y grupo criminal y el delito de tráfico de drogas cometido por persona que pertenece a una organización delictiva. Crónica de un conflicto normativo anunciado y análisis jurisprudencial", en Estudios Penales y Criminológicos, Vol. XXXIV, 2014, pág. 249 y ss.

25 Es bastante conocido que la Costa del Sol es un lugar donde desde los años noventa se han venido 
Por tanto, la necesidad en la legislación española de una regulación sobre criminalidad organizada transnacional, esto es, sobre el delito transnacional, tanto para la seguridad jurídica, como para el cumplimiento de obligaciones internacionales, resulta acuciante.

A los efectos de esclarecer los alcances de la noción de criminalidad organizada transnacional o delito transnacional, empezaré por la distinción entre delitos transnacionales y delitos internacionales.

\section{Distinción entre delitos transnacionales y delitos internacionales}

La erosión del principio de territorialidad de la ley penal no se ha dado solamente por la necesidad de evitar la impunidad en delitos que trascienden las fronteras nacionales, como los que son objeto de nuestro estudio. Al lado de este proceso, también se ha venido gestando un derecho penal internacional cuyo exponente máximo es el principio de justicia universal, es decir, el reconocimiento de una serie de principios, reglas, delitos cuya naturaleza trasciende la soberanía nacional porque interesa a toda la comunidad internacional.

Efectivamente, como pone de manifiesto el profesor Berdugo ${ }^{26}$, el proceso de internacionalización que ha sufrido el derecho penal, especialmente reforzado en los últimos años, es un movimiento que posee distintas manifestaciones: desde la protección de intereses de los que son titulares toda la comunidad internacional, hasta la aplicación por razones de utilidad de las normas penales más allá de las fronteras de los Estados que las emiten.

Por su parte Messuti27, al definir los crímenes internacionales, nos recuerda que hace ya un tiempo Saldaña realizó una clasificación de los mismos distinguiendo varias categorías:

En la primera, a) delitos de derecho internacional (interestatales) incluye

asentando organizaciones criminales de carácter internacional, llamándole las mafias italianas "la costa nostra". En un Reportaje de El País, "Metíamos toneladas de drogas en España en los noventa", de 29/12/2008, un capo narcotraficante contaba que en los años noventa ingresaban toneladas de cocaína por la falta de control de las fuerzas del orden. Una serie de factores, además, como la geografía, el clima, el idioma, el ambiente de fiesta, los bares, el alto consumo de drogas, etc., también favorecían el narcotráfico, pero sin duda, un punto fuerte de esta falta de prevención puede encontrarse en las leyes y su aplicabilidad por las operadores jurídicos.

26 Berdugo Gómez de la Torre, I., "Acerca de la internacionalización del Derecho Penal", en Pérez Cepeda (Dir.), El principio de justicia universal: fundamento y límites, Valencia, Tirant lo Blanch, 2012, pág. 22.

27 Messuti, A., Un deber ineludible. La obligación de los Estados de perseguir penalmente los crímenes internacionales, Buenos Aires, Ediar, 2013, pág. 190. 
aquellos delitos que constituyen una violación del orden jurídico internacional por parte de un Estado. Serían los que hoy denominamos "crímenes de guerra". En la segunda categoría, b) los delitos contra el derecho internacional (los antiguos delitos contra el derecho de gentes, donde incluye la piratería y atentados contra soberanos extranjeros. La tercera categoría, c) delitos que interesan al derecho internacional (internacionales), se configura a partir del lugar o de la jurisdicción. El autor señala que se denomina internacionales "por la forma" de comisión y los define como "el delito internacional es aquél cuyos elementos jurídicos, sociólogicos y antropológicos, están dispersos entre territorios, nacionalidades o razas diferentes". Menciona entre estos la esclavitud, la trata de personas, el banditismo internacional y el tráfico de armas. Y por último, la cuarta categoría, d) delitos según el derecho internacional (extranacionales), son delitos que existen porque existe un derecho de gentes 0 internacional, independiente de los derechos nacionales, que se reconocen por el carácter universal de los bienes jurídicos en juego. Entre estos menciona la piratería, el abordaje aéreo o marítimo, etc.

Sin duda, los delitos que nos ocupan de la criminalidad organizada transnacional se clasificarían en el tercer grupo claramente. Pero la clasificación resulta interesante porque, siendo muy antigua, muestra las dificultades de deslindar algunos casos como la piratería, que se presentó como la figura que ha dado lugar a las primeras reglas internacionales $y$, por tanto, a los inicios del derecho penal internacional, por la laguna de punibilidad que significaba el principio de territorialidad de la ley penal. Por otro lado, el carácter "internacional" de estos delitos, nos muestran un denominador común: que sus efectos trascienden las fronteras de los Estados, pueden afectar a numerosas víctimas, también de distintos Estados, adquieren especial gravedad, las dificultades de su persecución. Ahora bien, más allá de estas cuestiones generales que se comparten, hay particularidades que convienen distinguir.

Más modernamente Werle, en su famoso Tratado de Derecho Penal Internacional, emplea la denominación general de "crímenes de trascendencia internacional", considera que el criterio que determina la trascendencia internacional del delito es la relación con la comunidad internacional. Esta relación puede resultar, por una parte, de una necesidad de carácter práctico, y por otra, de la jerarquía de los intereses afectados. En el primer caso, son consideraciones de utilidad las que hacen necesaria la internacionalización del ilícito para facilitar su persecución, dada la impotencia de los Estados para hacerlo individualmente. "Es la especial manifestación de la criminalidad, en concreto su comisión transfronteriza, la que hace necesario el acuerdo y la cooperación entre los Estados para la persecución 
penal"28. En el segundo caso, en cambio, es el objeto del ataque, es decir, el bien jurídico afectado, lo que confiere dimensión internacional al delito.

En España esta discusión se ha dado al hilo de la naturaleza del principio de justicia universal, porque nuestra norma ha considerado aplicable esta jurisdicción, al lado de los delitos que representan un interés universal por afectar bienes jurídicos universales, a delitos en los que su fenomenología trasciende las fronteras de los Estados y, por tanto, hay un interés común en su persecución penal ${ }^{29}$. Ello, aunque por un lado amplía el principio de justicia universal a ámbitos más allá de los propiamente correspondientes, puede sembrar confusiones al no distinguir la distinta naturaleza de los mismos ${ }^{30}$. Por eso tiene razón Méndez Rodríguez cuando sostiene que:

coexisten hoy en día bajo este principio dos grupos de delitos cuya legitimidad para quedar al amparo del principio de justicia universal obedecería a razones claramente diversas, las que fundamentan tanto las doctrinas pragmáticas como las universalistas: el interés común en la persecución de estos delitos por tratarse de hechos de carácter transnacional que requieren el acuerdo de varios estados para que sea posible, o el interés común en su objeto de protección en cuya preservación están interesados todos los estados de la comunidad internacional ${ }^{31}$.

Aunque para algunos autores es de saludar la ampliación del principio de justicia universal a delitos transfronterizos, lo cierto es que la mayoría de la doctrina los distingue claramente cuando se trata de verificar su naturaleza. En suma, mientras los delitos internacionales se entienden como afrentas a bienes jurídicos de carácter universal, pues en su sustento están los derechos humanos reconocidos por el

28 Werle, G., Tratado de derecho penal internacional, Valencia, Tirant lo Blanch, 2005, pág. 95, diferencia dentro de ella los crímenes de derecho internacional, cometidos por individuos, de los actos ilícitos internacionales, cometidos por Estados.

29 Como ya se ha puesto de manifiesto con anterioridad, el art. 24.5 de la Ley Orgánica del Poder Judicial, al lado de los delitos propios de la jurisdicción universal, se contemplan delitos cuya forma de comisión es transfronteriza.

30 Pérez Cepeda, A., "Principio de justicia universal versus principio de jurisdicción universal", en de la misma, El principio de justicia universal: fundamento y límites, ob. cit., págs. 64-65, llama la atención sobre este aspecto, pues las obligaciones de los Estados son diferentes, así como las connotaciones políticas de los delitos internacionales suelen ser de mucha implicancia. Piénsese en los problemas que han suscitado la última reforma del principio de justicia universal que, al establecer tantas exigencias, ha producido el efecto de imposibilitar la jurisdicción en alta mar del tráfico de drogas, algo que ya se tenía por objeto de los jueces nacionales.

31 Méndez Rodríguez, C., "Delitos objeto del principio de justicia universal: naturaleza y límites”, en Pérez CEPEDA (Dir.), El principio de justicia universal: fundamento y límites, cit., pág. 326. 
derecho consuetudinario y las convenciones internacionales (ius cogens), en los delitos transnacionales el fundamento es de orden práctico: el interés de los Estados por llegar a acuerdos frente a formas de criminalidad que se cometen traspasando las barreras nacionales o en lugares donde la jurisdicción de los países no llega, como altamar. De todos modos no escapa al análisis que estos conceptos (como los Estados nacionales) no tienen, en algunos casos fronteras nítidas, como sucede con la piratería, que se considera ius cogens, pero también es una forma de criminalidad transnaciona ${ }^{32}$. Incluso se podría decir que algunas formas de criminalidad transnacional pueden amenazar la paz mundial. Piénsese en el terrorismo yihadista del llamado Estados Islámico, pero también en formas de criminalidad organizada no terrorista como el posible contrabando de armas nucleares o de sus componentes. Es verificable que dichos conceptos, por tanto, son dúctiles, pues hay supuestos donde no es fácil encajar claramente en una u otra categoría de delito.

Así, aunque en nuestra legislación estén todos estos supuestos dentro del principio de justicia universal, existe un consenso mayoritario en la doctrina de distinguir los propiamente delitos internacionales, de los delitos transnacionales 0 transfronterizos. De la naturaleza transnacional de algunos crímenes se desprende un derecho penal transnacional, mientras que de los crímenes internacionales se desprende un derecho penal internacional ${ }^{33}$. Según algunos autores se podría hablar, pues, de propiamente un derecho penal transnacional que comprende tanto la normativa internacional sobre la materia, como la normativa interna correspondiente a la represión de la delincuencia transfronteriza 0 al desarrollo de las líneas de actuación dentro de los confines de los Estados frente a esta delincuencia, esto es, cooperación policial y judicial, principalmente ${ }^{34}$.

En síntesis, distinguiendo los delitos internacionales de los delitos transnacionales éstos últimos lesionan bienes jurídicos nacionales comunes de varios Estados, mientras que los primeros tratan de bienes jurídicos supranacionales

32 No me puedo extender sobre ello. Vid. Méndez Rodríguez, "Delitos objeto del principio de justicia universal: naturaleza y límites", cit., pág. 329, quien pone de relieve: "el delito de piratería, perteneciente tradicionalmente al derecho de gentes, precisamente como delito iuris gentium, ofende "a la comunidad internacional en su conjunto", y sin embargo no se habría incorporado al Estatuto de la Corte Penal Internacional", al señalar ese núcleo duro de los delitos internacionales, como los cuatro delitos incorporados a dicho Estatuto.

33 Cfr. Rosı, E., "La legge n. 146 del 16 marzo 2006 sul crimine organizzato transnazionale. In particolare, gli aspetti problematici della definizione di reato transnazionale. Aspetti problematici della definizione di reato transnazionale", en http://www.immigrazione. biz/upload/legge n 146 del 16 marzo_2006_sul_crimine_organizzato_transnazionale.pdf, pág. 2.

34 Ibidem. 
propios del ius cogens que afectan a una Civitas máxima. Por tanto, los primeros vulneran el derecho internacional, mientras que los segundos tanto el derecho interno como el derecho internacional. En los primeros se trata de la búsqueda de una responsabilidad penal individual internacional directa, en los segundos de la búsqueda de una responsabilidad penal en el ámbito de organizaciones, indirecta, a través del derecho interno ${ }^{35}$.

Indudablemente las diferencias entre ambas formas de delincuencia han de imprimir notables distinciones jurídicas en el tratamiento penal, pero no puede negarse que la doctrina y la jurisprudencia de una y otra, pueden ser útiles para desarrollar categorías que aún no están totalmente pergeñadas por tratarse de nuevas formas de criminalidad. Piénsese en el concepto de organización que sí está reconocido en el Derecho Penal Internacional ${ }^{36}$ y no tan fácilmente en las legislaciones nacionales. 0 , la participación en grupo ${ }^{37}$, que reconoce el Estatuto de la Corte Penal Internacional y, no es propio del derecho penal interno normalmente. Todos estos conceptos, si se tiene una mentalidad amplia ${ }^{38}$, pueden ser de gran utilidad para ir delimitando nociones a los efectos de hacer frente a la criminalidad organizada transnacional, tan huérfana de los mismos por los derechos internos.

\section{Una propuesta de mínimos: criminalidad organizada transnacional / delito transnacional}

Se ha señalado que el punto de arranque de la noción de criminalidad organizada transnacional necesariamente lo tenemos que ver en la Convención de Naciones Unidas contra la Criminalidad Organizada Transnacional, porque se trata del primer acuerdo internacional sobre la materia. No obstante, a los efectos de afinar el concepto de criminalidad organizada transnacional es preciso tener en cuenta una cuestión metodológica: cuando hablamos de criminalidad organizada transnacional

35 Cfr. Messutı, Un deber ineludible, cit., pág. 196.

36 Cfr. AmBos, K., "Sobre 'la organización' en el dominio de la organización", en Indret, N³, 2011, donde el autor estudia las características de las organizaciones estatales y sus vinculaciones con otras organizaciones para la perpetración de crímenes contra la humanidad, comentando la sentencia del caso Fujimori.

37 Cfr. Kıss, A., "La contribución en la comisión de un crimen por un grupo de personas en la jurisprudencia de la Corte Penal Internacional", en Indret, № 2, 2013, donde el autor analiza la diferenciación entre la contribución en el crimen cometido por un grupo y la coautoría, al hilo del art. 25.3.d del Estatuto de Roma y la jurisprudencia internacional.

38 Sartori, G., "Comparación y método comparativo", en Sartori / Morlino, La comparación en ciencias sociales, Madrid, Alianza Editorial, 2002, 1ª reimpresión, pág. 33. 
estamos refiriéndonos a una realidad criminológica, mientras que cuando hablamos de delito transnacional nos referimos a un concepto jurídico. Sobre el difícil traspaso de la noción sociológica a la noción jurídica y la complejidad que alumbra todo este análisis, me referiré en los dos epígrafes siguientes.

Pero antes es preciso señalar que, como nos recuerda Centonze, la Convención ha afirmado una noción de criminalidad organizada transnacional de naturaleza multifuncional, idónea para comprender una pluralidad de fenomenologías criminales caracterizadas por presentar una dimensión extra-territorial ${ }^{39}$. No podía ser de otra manera, la Convención tenía que reunir en unos conceptos una multiplicidad de comportamientos muy distintos, de diferentes culturas y países. Siguiendo a Sartori ${ }^{40}$, mientras más generalizante sea un concepto, "más capacidad de viaje" tendrá. Este autor utiliza este símil para denotar que las teorías generales en ciencias sociales tendrán un mayor poder de comprensión de la realidad, que las menos generalizantes. También es verdad que mientras más generalizante sea la definición, menos atención se presta a las particularidades y siempre habrá casos que puedan plantear problemas de interpretación.

Centonze también destaca que en la elaboración de la Convención de Palermo se impuso la construcción científica del criminólogo estadounidense Gerhard 0. W. Mueller, que se utilizó por primera vez en el seno del V Congreso de Naciones Unidas de 1975, con la expresión anglosajona de transnational crime. De ahí también la nomenclatura que ha ganado terreno: criminalidad organizada transnacional, de impronta anglosajona. Tras este Congreso de Naciones Unidas quedó asentado que cuando se denomina criminalidad organizada transnacional, se trata del fenómeno criminal que trasciende las fronteras de los territorios nacionales, y que por tanto, transgrede las leyes de diversos Estados, o que tienen un impacto sobre otro país. En síntesis, se hace referencia a la actividad delictiva que se extiende dentro de distintos países y violando sus respectivas legislaciones ${ }^{41}$.

39 Centonze, A., Criminalità organizzata e reati transnazionali, Milán, Giuffrè, 2008, pág. 167.

40 SARTORI, "Comparación y método comparativo", cit., págs. 44 y 45: "... la elección entre individualizar y generalizar es una opción que se impone. Por lo tanto es de interés establecer, siempre en clave de método, cómo convertir o al menos relacionar los dos procedimientos.....un método capaz de organizar universales y particularidades es organizar nuestras categorías a lo largo de escalas de abstracción regidas por la regla de transformación (tanto en dirección ascendente como descendente. De este modo con la finalidad de hacer un concepto más general -incrementando también su capacidad de viajar- debemos reducir sus características o propiedades. A la inversa, con la finalidad de hacer un concepto más específico -y entonces contextualmente más adecuado- debemos aumentar las propiedades o características.

41 Cfr. LleRena, P., “La criminalidad organizada transnacional y finanzas", en la red, pág. 1. Quien cita la 


\subsection{La complejidad: el todo y las partes}

Tiene razón Aleo cuando enmarca el análisis de la criminalidad organizada general y la criminalidad organizada transnacional en particular, en la categoría de la complejidad. Sólo se puede comprender esta forma de criminalidad, en un proceso de carácter general, en el que la palabra crisis, simplemente pone en evidencia la incapacidad de las categorías tradicionales para comprender el significado de realidades en transformación como la democracia, las funciones del Estado social, la crisis de la lógica formal, la cultura de la relatividad y de la contextualización, en general la superación de las dimensiones nacionales de todas las actividades humanas, esto es, la cultura de la complejidad ${ }^{42}$.

Por tanto, al hablar de criminalidad organizada transnacional se trata de diversos niveles de análisis que se entrecruzan sincrónica y diacrónicamente. La utilización de la teoría de los sistemas, la noción de redes, son todas categorías que denotan dicha complejidad. Nos encontramos ante un fenómeno social complejo, en el que se entrecruzan tantos otros fenómenos sociales y complejos, como el terrorismo, la corrupción pública y privada, la criminalidad de empresa, etc., por lo que también se pueden sobreponer -como lo hacen siempre los fenómenos histórico-sociales-43, 0 confundirse en la realidad, en los cuales resulta difícil delimitar fronteras, definir conceptos, establecer clasificaciones.

Empezando porque el carácter transnacional es un adjetivo de una forma de criminalidad ya compleja como lo es la criminalidad organizada. Un primer punto, entonces, del análisis debe empezar por establecer si la criminalidad organizada transnacional es una especie de la forma más general de criminalidad organizada. Esto es, si la criminalidad organizada transnacional presupone necesariamente el concepto de criminalidad organizada y, por tanto, de organización. Para Rosi, no se entiende por qué se deba reducir la noción de delito transnacional a las manifestaciones de la criminalidad organizada. Para esta autora, la transnacionalidad no es un subsistema de los delitos que evidencian comportamientos de grupos

ponencia de Alfredo Nunzi, "The Elaboration of the United Nations Convention against Transnational Organized Crime", presentado por ISISC en el XVI Congreso Internacional de Derecho Penal, Budapest, Hungría, septiembre de 1999, para ver una evolución del concepto.

42 Aleo, S. "Criminalità transnazionale e definizione della criminalità organizzata: il requisito dell'organizzazione", en Nuove strategie per la lotta al crimine organizzato transnazionale, Turín, Giappichelli, 2003, pág. 10.

43 Cfr. Caciaglı, M., Clientelismo, corrupción y criminalidad organizada, Madrid, Centro de Estudios Judiciales, 1996, págs. 10-11. 
organizados, sino más bien un sistema autónomo, sólo en parte coincidente con la criminalidad organizada ${ }^{44}$.

La pregunta que ha de hacerse es icabe pensar en supuestos de delitos de carácter transnacional en los que no exista organización? A mi entender la respuesta es a todas luces negativa, las actividades delictivas de carácter transnacional necesariamente presuponen una organización, porque necesariamente presupone una forma de criminalidad organizada, dado que para llevar a cabo las conexiones de las actividades internacionales se requiere de una estructura, unas interconexiones de personas y medios, a lo que criminológicamente denominamos organización criminal ${ }^{45}$. Asílo entiende Aleo para quien en el centro de la criminalidad transnacional y de la criminalidad organizada está la organización criminal ${ }^{46}$. Otra cosa es que muchas veces no sea fácil comprobar dichas conexiones, la estructura, etc., porque se trate de redes flexibles, pequeñas, grandes, etc. ${ }^{47}$. De hecho, la definición de criminalidad organizada transnacional de la Convención de Palermo comprende también de esta manera, como enseguida se verá.

Con carácter general se puede afirmar que los fenómenos organizativos de la actividad delictuosa han seguido la tendencia general y progresiva de la agregación, organización e integración, por consiguiente mayor dimensión, complejidad y relevancia de todas las actividades humanas: la tendencia a la unión y acuerdo entre individuos, a la profesionalización y la especialización, la industrialización y división del trabajo, internacionalización y, por último, globalización ${ }^{48}$. En definitiva, así como

44 Rosı, "La legge n. 146 del 16 marzo 2006 sul crimine organizzato transnazionale", cit., pág. 8.

45 Sobre el contenido del concepto de organización criminal, me extenderé más adelante.

46 Como advierte Aleo, S., "Criminalità transnazionale e definizione della criminalità organizzata: il requisito dell'organizzazione", cit., pág. 11: La organización puede considerarse en general una figura de la complejidad.

47 La jurisprudencia española es, a veces, contradictoria a la hora de valorar supuestos de tráfico de drogas de carácter internacional. Para muestra la STS Nº 780/2013, de 25 de octubre, en la que el Tribunal Supremo absuelve a Juan Manuel por el delito de pertenencia a organización criminal, pese a que el Servicio de Vigilancia Aduanera encontró en su barco, en altamar, 2.245 kg de cocaína con una riqueza media del $17,5 \%$, existían escuchas telefónicas que muestran las vinculaciones con otros implicados, testimonios de los agentes, etc. , pero lo que el TS no acaba de ver es la pertenencia de Juan Manuel a una organización criminal. Según este Tribunal «no existen pruebas de que formara parte de una organización delictiva que se dedicara al tráfico de drogas, pues para ello es preciso acreditar algo más que la pluralidad de intervinientes». Vid. más ampliamente ZúÑIGa RodríGuez, L., "Comentario a la Sentencia del Tribunal Supremo (Sala de lo Penal), 780/2013, de 25 de octubre (ROJ STS 5239/2013). Valoración de la prueba. Tráfico ilícito de drogas", en Ars Juris Salmanticensis, Vol. 2, 2014, págs. 355-358.

48 Cfr. Aleo, S., Sistema penale e criminalità organizzata. Le figure delittose associative, Milán, Giuffré, 1999, pág. 6 . 
en todas las tareas humanas se ha tendido a una colectivización del trabajo, a la unión de personas para lograr fines comunes, así también en el ámbito de la criminalidad se ha desarrollado la tendencia a una colectivización de la actividad delictuosa para maximizar los beneficios de las mismas. Así, como no podía ser de otra manera, el proceso de la colectivización de las relaciones sociales ha supuesto también la colectivización de la actividad crimina/49 . La globalización le ha supuesto un paso más en su desarrollo, adquiriendo carácter internacional las actividades delictivas en el juego de oferta y demanda de objetos y servicios ilícitos de un país a otro. Los tráficos ilícitos internacionales, de los que nos estamos ocupando, comportan relaciones en redes de colaboración para la ejecución de los mismos, en lo que respecta a la obtención del bien ilícito, los medios de transporte, la compra y venta de los objetos ilícitos, provisión de bienes para el mantenimiento de la estructura criminal, etc., sin olvidar que en muchos casos se requiere además colaboración de operadores policiales y judiciales, contratación de profesionales especializados, etc. En suma, todo esto necesariamente requiere una organización. El hecho de que no siempre sea posible verificar la existencia de la organización, no significa que no la haya.

Tanto la realidad criminológica, como la aprehensión de ella por la norma penal poseen una dimensión distinta a la llamada criminalidad común ${ }^{50}$, fundamentalmente porque las coordenadas de racionalidad penal se han construido desde la responsabilidad individual ${ }^{51} \mathrm{y}$, en estos casos, estamos ante comportamientos de

49 Queda así patente que el fenómeno criminal es un fenómeno social, que cada sociedad produce su propia criminalidad, algo que para la mayoría de sociólogos y criminólogos parece evidente, pero que para los juristas positivistas resulta un anatema. No habría que hacer esta nota, si no fuera porque las tendencias políticocriminales actuales privilegian una visión de la criminalidad desconectada de su sociedad, incidiendo en la represión y acallando o negando los paradigmas etiológicos, en suma, desresponsabilizando a la sociedad de sus propios fenómenos. Cfr. ZúñIGa Rodríguez, L., "Viejas y nuevas tendencias políticocriminales en las legislaciones actuales", en Berdugo Gómez de LA Torre / Sanz Mulas, Derecho Penal de la democracia vs. Seguridad pública, Granada, Comares, 2005, passim, especialmente págs. 125-129.

50 Nótese que "criminalidad común" se usa en oposición a cualquier tipo de criminalidad especial (terrorista, socioeconómica, etc.). En el texto se usa como expresión de los delitos clásicos (Derecho Penal clásico): homicidios, robos, violaciones, etc.

51 Sobre este hecho llama la atención en nuestro medio Quintero Olivares, "La criminalidad organizada y la función del delito de asociación ilícita", en FerRé Olivé / Anarte (Eds.), Delincuencia organizada. Aspectos penales, procesales y criminológicos, Univ. de Huelva / Fundación El Monte, 1999, pág. 178: "Frente a la criminalidad del gran grupo el derecho penal no ha tenido por lo común una especial manifestación, tal vez porque tampoco la podía tener. Desde un planteamiento del delito y de la responsabilidad como algo referido a la conducta del individuo aislado, tan sólo se han formulado algunas figuras legales orientadas a comprender la agrupación de personas en la comisión organizada de delitos". 
organizaciones. Como sostiene Medina Ariza, "el crimen organizado no puede ser definido exclusivamente por unos actos, sino también debe referirse a las personas que trabajan juntas como grupo para cometer dichos actos" 52 . Caracterizar a la criminalidad organizada por los delitos que comete supondría renunciar a una definición común de la misma, y, por tanto, sería un abandono de su prevención y represión como fenómeno criminal que adquiere ciertas características propias.

Entonces, ha de convenirse que en la base de la noción de criminalidad organizada transnacional, está la noción de criminalidad organizada, y detrás de ésta encontramos la categoría organización criminal, siendo simplemente el carácter transnacional que se agrega a la categoría general. Si es así, como puede preverse, se desprende fácilmente su carácter de mayor gravedad respecto a la criminalidad común y a la propia criminalidad organizada, en la medida que se añaden más características que denotan complejidad y, por tanto, una organización criminal estructurada, con mayor capacidad para la realización de las actividades ilícitas. Se podría sostener que el carácter transnacional de la organización criminal se trata de un plus respecto a la criminalidad organizada común.

Así lo entienden las legislaciones más modernas ${ }^{53}$ y así lo entienden también las fuerzas policiales en la medida que las organizaciones criminales que realizan activides internacionales requieren de una mayor estructura ${ }^{54}$. Es decir, es algo asumido por las realidades sociales en nuestro entorno cultural, no siempre visualizado en el ámbito jurídico.

Ello es así, por diversas razones. En primer lugar porque la responsabilidad penal centrada en el individuo, conforme a las categorías clásicas del derecho penal, impide

52 "Una introducción al estudio del crimen organizado", en Ferré Olivé / Anarte (Eds.), Delincuencia organizada. Aspectos penales, procesales y criminológicos, Univ. de Huelva / Fundación El Monte, 1999, pág. 111

53 Por ejemplo, la Ley $N^{0}$ 12.850, de 2 de agosto de 2013 que define la organización criminal y dispone sobre la investigación criminal y los medios de prueba, dispone en el art. 1.1: "Se entiende por organización criminal la agrupación de 4 (cuatro) 0 más personas estructuralmente ordenada y caracterizada por la división de tareas, incluso informalmente, con el objetivo de obtener directa o indirectamente una ventaja de cualquier naturaleza, mediante la práctica de infracciones penales cuyas penas máximas sean superiores a 4 (cuatro) años, o que sean de carácter transnacional".

54 El avance de la internacionalización de las actividades de las organizaciones criminales en España es palpable. Así, en el último Balance de la lucha contra el Crimen Organizado en España, del Ministerio del Interior, 2013, se detecta que el 67\% de los grupos presenta actividad internacional. Además, el porcentaje mayoritario dedicado al tráfico de drogas que es una actividad internacional, confirma esta tendencia. Según estos datos, del total de delitos cometidos por el crimen organizado, 31\% se dedicaba al tráfico de cocaína y $21 \%$ al tráfico de hachís. Fuente: http://www.interior.gob.es/web/ interior/prensa/balances-e-informes/2013. 
-en muchos casos- ver la responsabilidad en su conjunto del grupo estructurado, como es la fenomenología de actuación de la criminalidad organizada. Afirmándolo coloquialmente: "Ios jueces suelen ver los árboles, pero no ver el bosque" 55 . 0, dicho de otro modo, la manera de interpretar la responsabilidad penal desde un individuo, hace que tradicionalmente se vea "las partes" y no se vea el "todo"56. Ello conlleva, en muchos casos, la absolución de los procesados y, por consiguiente, la impunidad de conductas que, vistas en su conjunto, son auténticamente graves y afectan de manera intolerable a la convivencia social. Como afirma Velasco Núñez, "el papel concreto en la ejecución global de cada específico componente no deja conocer el conjunto de la acción así fragmentada y atomizada que, es por ello, más difícil de prevenir, evitar, probar y castigar" 57 .

$Y$ es que el injusto de las conductas de los tipos penales de organización criminal tienen una estructura compleja: primero, la afirmación de la existencia de una organización criminal y, en segundo lugar, diversos grados de participación en dicha organización criminal. Es decir, primero habrá que probar la existencia de una organización criminal, tanto el tipo objetivo (cantidad de personas, estructura estable) como el tipo subjetivo (finalidad de comisión de delitos graves, con la finalidad ulterior de obtener un beneficio económico), para en segundo lugar, comprobar el grado de participación concreto en dicha organización de la persona (fundador, dirigente, miembro activo, etc.), bastando normalmente con una participación activa.

Un segundo aspecto de la complejidad es que, al ser la comisión de delitos por parte de la criminalidad organizada realmente una forma de actuación, donde la afección a los bienes jurídicos se realiza utilizando las estructuras de una organización criminal, esto es, un injusto de organización crimina/58, existen detrás delitos concretos

55 Similarmente, el juez de la Audiencia Nacional que tiene el privilegio de observar este hecho en el día a día, Velasco Núñez, E., "Crimen organizado: organización y grupo criminal tras la reforma del Código Penal en la L0 5/ 2010", en La Ley, No 16986, 2011, pág. 10. "Las ramas no dejan ver el bosque".

56 Parafraseando el título de la Lección Inaugural del Curso Académico 2014/2015 de la Universidad de Salamanca, de Gónzález Alonso, B., El Todo y las Partes. Una aproximación jurídico-institucional al proceso de formación de España y de su organización territorial, Universidad de Salamanca, 2014, aludiendo a la construcción de España como un Todo, compuesto por diversas Partes. Sostiene: “... ni España -el Todo-, ni las porciones que la componen -las Partes- han existido siempre", pág. 10.

57 Velasco Núñez, E., “Crimen organizado: organización y grupo criminal tras la reforma del Código Penal en la L0 5/ 2010", cit., pág. 10.

58 ZúñIga Rodríguez, Criminalidad organizada y sistema del Derecho Penal. Contribución a la determinación del injusto penal de organización criminal, Granada, Comares, 2009, págs. 249 y ss., donde se explica el plus de desvalor de la existencia de una estructura idónea para delinquir (realizar el programa criminal) y la necesidad de su regulación en la Parte General. 
que son los que tradicionalmente han sido estudiados. Es decir, la problemática de la criminalidad organizada transnacional comprende la problemática de los tipos de delitos que ella comete. Esto se evidencia claramente con el delito de tráfico de drogas, donde las rutas a nivel mundial de las sustancias estupefacientes denotan comportamientos que necesariamente afectan las fronteras de varios países. Ello conlleva que la regulación jurídica aplicable sea como Militello define multinivel: una dinámica de fuentes nacionales e internacionales, donde la lógica deductiva clásica de supremacía jerárquica de la ley no se resuelve fácilmente, entrando a tallar nuevas formas de influencia recíproca e interacción. Todo un reto para la ciencia penal ${ }^{59}$.

\subsection{De las nociones criminológicas a las nociones jurídicas}

Como en tantas ocasiones, la realidad criminológica precede a la elaboración jurídica en la criminalidad organizada transnacional. Más aún, la criminalidad organizada ha tenido, desde el punto de vista histórico, primeramente una fenomenología de actuación en la sociedad, en la que muchas de sus conductas no han sido siempre percibidas como delictuosas, pues correspondían a comportamientos asumidos como adecuados dentro de la propia cultura. Es lo que sucedió con la mafia siciliana, por ejemplo, donde los comportamientos de omertà, hombres honorables, etc., estuvieron asentados durante siglos al considerarse legitimados por enfrentarse a poderes abusivos. La historia del crimen organizado tiene un largo pasado en distintos países, configurando diversos comportamientos considerados delictivos y, muchos border crimes que no siempre han tenido represión penal.

La cuestión que ahora se trata de abordar es iqué noción de criminalidad organizada es la que se ha impuesto en la regulación de criminalidad organizada transnacional de la Convención de Palermo? Y ¿cuál noción de criminalidad organizada es la que debe prevalecer en las normas?

Capturar en una noción general sobre criminalidad organizada, la multiplicidad de fenómenos que en ella se desarrollan, es una tarea prácticamente imposible. Se ha dicho con anterioridad que ha primado en la Convención de Palermo una noción de criminalidad organizada de orden criminológico y, concretamente, de impronta anglosajona. El traslado de construcciones criminológicas a los textos jurídicos no es nada fácil.

59 Cfr. Mııтello, V., "L’identità della scienza giuridica penale nell'ordinamento multilivello", en Rivista italiana di Diritto e procedure penale, Fascículo 1, 2014, págs. 106 y ss. Un aspecto muy relevante de la discusión actual de la dogmática penal, en el que no me puedo extender, remitiendo a ese trabajo. Especialmente destaco las tensiones entre las garantías y el respeto a los derechos fundamentales en los derechos nacionales, frente al peso de la seguridad en los Convenios Internacionales. 
En realidad la concepción de criminalidad organizada se ha desarrollado primero en el ámbito sociológico o criminológico y su trasvase a la legislación penal ha planteado serias dificultades porque las herramientas conceptuales del derecho penal no pueden descifrar todos los códigos que la realidad fenomenológica de la misma posee. La falta de acuerdo en la regulación, la utilización de técnicas de investigación que constituyen limitaciones a derechos fundamentales, son todas pruebas de dichas dificultades. Las dificultades estriban en consideraciones de orden metodológico que han sido objeto de controversia durante todo el desarrollo histórico del derecho penal: cómo conocer un fenómeno social con el método jurídico-penal. En otros términos, cómo pasar del hecho social al hecho jurídico, del "ser" al "deber ser", de las proposiciones descriptivas a las proposiciones prescriptivas. Las dificultades metodológicas se acrecientan cuando ha de hacerse frente a comportamientos criminales que poseen una dimensión de fenómeno social, que para muchas personas constituye su moyen de vivre, como sucede con la criminalidad organizada. El derecho penal se enfrenta ante el desafío de aprehender un fenómeno social con unas herramientas conceptuales propias de un comportamiento individual, en el que, seguramente, los fines, los principios y las categorías que conocemos no son idóneos para prevenir la constelación de comportamientos criminales que subyacen en esa dimensión social.

Efectivamente, la óptica del criminólogo sería muy distinta a la de las agencias de control social. Mientras que para el criminólogo se trataría de buscar una definición que posea la utilidad de comprender dicha realidad, para el jurista se trataría de elaborar definiciones que corresponden a fines de tipo jurídico y judicial, con el objetivo de proporcionar instrumentos de lucha contra el comportamiento ilícito que se intenta evitar ${ }^{60}$. La primera óptica corresponde más a la búsqueda de causas, factores, características, en suma, a la prevención o la reacción proactiva; mientras que la óptica jurídica incide más en la represión, en la reacción reactiva.

Ahora bien, las dificultades de "capturar" en una ley fenómenos sociales tan cambiantes, no eximen de la necesidad de la búsqueda. No por ello debe cejarse en el empeño. Así como ha sido difícil definir el terrorismo, la corrupción u otros fenómenos criminales, y no por ello se han dejado de reprimir y castigar, así también la criminalidad organizada transnacional requiere de elementos de definición.

En suma, tomando las palabras de Medina Ariza, uno de los pocos criminólogos españoles que se ha ocupado del tema, "una definición conceptual clara del crimen

60 Ibidem, pág. 5. Esa diversidad de objetivos sería uno de los muchos "errores" del control de la criminalidad organizada. 
organizado resulta esencial. De ninguna manera podremos medir, ni combatir el crimen organizado si no nos ponemos de acuerdo en la realidad que esta etiqueta captura"61. Además, decir lo que la criminalidad organizada es y qué tipo de actividades criminales envuelve, ayuda a examinar por qué ocurre, cuándo y cómo lo hace, lo cual desvela, en definitiva, claves para controlarlo ${ }^{62}$.

Varios autores han puesto en evidencia las disímiles características de la criminalidad organizada, como un fenómeno dinámico, siempre en continuo cambio, muy interesado en ir adaptándose a las fisuras de la sociedad. Según esta observación, que es más de tipo sociológico, no sería posible capturar en una definición un fenómeno tan proteico como este. Como pusieron de manifiesto en 1987 Ferracutti y Bruno, el desafío de la Criminología y del Estado es la rapidez y el carácter proteico del fenómeno, siempre expresión de un anticipo de las propias transformaciones sociales y, por tanto, la insuficiencia de los tradicionales instrumentos criminológicos, sobre todo, porque es un fenómeno que no se pone en neta antítesis con los valores de la sociedad "sana" y, por tanto, no es "patologizable"63. Esto le ha dado cierta nota de diversidad en la realidad de las actividades, móviles, estructuras que conforman el mundo de lo que denominamos criminalidad organizada. Por eso el universo de lo que se entiende por criminalidad organizada constituye una clasificación de la criminalidad bastante amplia, en la medida que comprenden delitos diversos, modos de cometerlos disímiles, móviles distintos, cantidad de personas variables, etc.

Hoy la gran criminalidad ha devenido "otra" -como afirma Ponti64 - respecto a lo que el criminólogo ha estado habituado a considerar su objeto de estudio. El campo de la Criminología ha sido siempre los delitos y sólo marginalmente se ha ocupado de la desviación no delictuosa. La Criminología no se ha ocupado nunca de conductas o fenómenos que eran expresiones de un poder paralelo, en el que hay conductas o fenómenos que son compenetraciones, colusiones, alianzas, consensos con las áreas de la legitimidad. La Criminología ha trabajado bien cuando era clara la línea entre lo lícito y lo ilícito y no posee las herramientas para conceptuar hechos sociales con notable incidencia en la propia sociedad legítima. Nos referimos, por supuesto a las figuras sociales "adyacentes" (especialmente los trabajadores white collar)

61 Medina Ariza, "Una introducción al estudio criminológico del crimen organizado", cit., pág. 111.

62 Ibidem, pág. 110.

63 Cfr. Ponti, G., "Criminalità organizzata e criminología", en Bandinı / Lagazzi / Marugo /, La Criminalità Organizzata. Moderne metodologie di ricerca e nuove ipotesi esplicative, Milán, Giuffrè, 1993, pág. 180.

64 Ibidem, págs. 184-185. 
que realizan "su trabajo" pero que al mismo tiempo colaboran con organizaciones criminales. Este es uno de los aspectos que más preocupa a los organismos internacionales ${ }^{65}$, por las dificultades en su persecución.

El núcleo de las conductas de la criminalidad organizada lo constituyen las organizaciones criminales. Esto es, el concepto básico criminológico es la organización criminal, cuyo contenido se ha ido perfilando con los conocimientos criminológicos, así como con los contenidos normativos. Ya que es una categoría que necesariamente posee elementos naturales y elementos normativos, difíciles de deslindar, puesto que el adjetivo criminal es a todas luces normativo. Empezaremos por los elementos naturales.

La caracterización más aceptada -al menos en Europa- parece ser la de EUROPOL ${ }^{66}$, que establece 11 indicadores: 1. Más de dos personas. 2. Distribución de tareas entre ellas. 3. Permanencia. 4. Control interno. 5. Sospechosos de la comisión de delitos graves. 6. Actividad internacional. 7. Violencia. 8. Uso de estructuras comerciales o negocios. 9. Blanqueo de dinero. 10. Presión sobre el poder político. 11. Ánimo de lucro, siendo 1, 5 y 11 obligatorias. Es decir, más de dos personas, sospechosas de delitos graves y con ánimo de lucro.

La ventaja de esta caracterización es que pone el acento en los aspectos centrales, fundamentales y, luego señala otros aspectos que pueden agregarse 0 no según las diversas circunstancias. A los efectos de este trabajo y, para señalar las características necesarias de la organización criminal, núcleo de la criminalidad organizada, reafirmaré las siguientes características: unión de dos o más personas, sospechosas de la comisión de delitos graves y que actúan con ánimo de lucro. Como puede verse, otras características muy recurrentes en la criminalidad organizada, como el uso de la violencia, no son definitorias, sino más bien, contingentes.

65 Cfr. Parlamento Europeo, Working document on organized crime, Special committee on organized crime, corruption and money laundering, Relator Salvatore lacolino, DT/913961, en doc, 2009-2014, pág. 12, en su recomendación f) señala: "alentar y educar a los partidos en la responsabilidad política con el fin de garantizar que las listas electorales se elaboren de acuerdo a un riguroso código ético, sin perjuicio del principio de inelegibilidad para ser miembro del Parlamento Europeo, de cualquier condenado mediante sentencia firme por la participación en la delincuencia organizada, el blanqueo de dinero, la corrupción u otros delitos graves contra la administración pública". También la Resolución del Parlamento Europeo, de 25 de octubre de 2011, sobre la delincuencia organizada en la Unión Europea (2010/2309(INI)), establece en el considerando C): "la delincuencia organizada se ha infiltrado profundamente y se ha consolidado en el mundo de la política, la administración pública y la economía legal en algunos Estados miembros".

66 Lo siguen las fuerzas policiales españolas, por supuesto, lo que ha permitido los avances en materia de cooperación policial, pero también los Informes de la Unión Europea. Cfr. Parlamento Europeo, Working document on organized crime, cit., pág. 3. 
Ahora bien, para comprender el trasvase al ámbito jurídico, es preciso acudir a las normas internacionales. Esto es, la Convención de Palermo y la normativa europea. Veremos cómo, desde el punto de vista jurídico, la figura punible básica es la participación en organización criminal.

\subsection{Naciones Unidas y la Convención de Palermo}

La Convención de Naciones Unidas contra la Criminalidad Organizada Transnacional establece que su finalidad es "promover la cooperación para prevenir y combatir más eficazmente" este fenómeno criminal (art. 1). Ello quiere decir que el fin último de este acuerdo internacional es el acercamiento de los países en definir qué es el delito transnacional, toda vez que se trata de un flagelo que requiere de la necesaria cooperación de los Estados. Para ello se requiere una armonización mínima de las legislaciones nacionales, empezando por los conceptos que se encuentran en su base.

De ahí que el art. 2 se ocupe de establecer definiciones sobre sus elementos básicos, a saber: "grupo delictivo organizado", "delito grave", "grupo estructurado", y otras más, pero a los efectos de nuestro objeto de estudio conviene evocar estos tres:

a) Por "grupo delictivo organizado" se entenderá un grupo estructurado de tres o más personas que exista durante cierto tiempo y que actúe concertadamente con el propósito de cometer uno o más delitos graves o delitos tipificados con arreglo a la presente Convención con miras a obtener, directa 0 indirectamente, un beneficio económico u otro beneficio de orden material;

b) Por "delito grave" se entenderá la conducta que constituya un delito punible con una privación de libertad máxima de al menos cuatro años o con una pena más grave;

c) Por "grupo estructurado" se entenderá un grupo no formado fortuitamente para la comisión inmediata de un delito y en el que no necesariamente se haya asignado a sus miembros funciones formalmente definidas ni haya continuidad en la condición de miembro o exista una estructura desarrollada.

La Convención adopta dos definiciones de organización criminal, una fuerte y otra débil: el "grupo delictivo organizado", con las exigencias criminológicas antes señaladas de unión de personas ( 3 o más), con cierta permanencia en el tiempo (estructura) y que actúe concertadamente (reparto de tareas), para cometer delitos graves o los tipificados en la Convención, con la finalidad de un beneficio económico (ánimo de lucro). Con esta última característica la Convención deja fuera de su aplicación y, por tanto, de la comprensión de criminalidad organizada (transnacional) 
el terrorismo, en el buen entender de que en estos casos se trata de supuestos que, aunque tengan en común la organización criminal, su finalidad política es totalmente distinta a esta forma de criminalidad. Puede que en la realidad se entrecrucen como sucede con muchos fenómenos sociales, pero desde el punto de vista jurídico y de propuestas político-criminales son fenómenos criminales muy distintos.

Por su parte el "grupo estructurado" definido "en negativo", parece más bien una definición que posee menos fuerza en sus características, un tanto residual (no hay reparto de roles, no hay continuidad de sus miembros, no muy desarrollada), cuando no se ha conseguido reunir todas las características de la definición fuerte. El umbral de "grupo no formado fortuitamente para la comisión inmediata de un delito", solo se comprende para deslindar grupos criminales de la figura de la coautoría propia de los sistemas jurídico-penales. Ahora bien, considero, como enseguida fundamentaré que el "grupo estructurado", no está en el núcleo de la criminalidad organizada transnacional. Sólo lo está el grupo criminal organizado, como a continuación se verá.

Así es, si nos atenemos al ámbito de aplicación de la Convención, el art. 3 establece:

1. A menos que contenga una disposición en contrario, la presente Convención se aplicará a la prevención, la investigación y el enjuiciamiento de:

a) Los delitos tipificados con arreglo a los artículos $5,6,8$ y 23 de la presente Convención; y

b) Los delitos graves que se definen en el artículo 2 de la presente Convención; cuando esos delitos sean de carácter transnacional y entrañen la participación de un grupo delictivo organizado.

Esta disposición señala a qué delitos se refiere la criminalidad organizada transnacional, estableciendo dos fórmulas: una, identificando los delitos concretos, esto es, participación en un grupo delictivo organizado (art. 5), blanqueo del producto del delito (art. 6), corrupción (art. 8) y obstrucción a la justicia (art. 23); y la segunda, haciendo referencia a la gravedad del delito, esto es, una fórmula abierta teniendo como referencia el nivel de sancionabilidad de las penas. Teniendo en cuenta que los delitos concretos a que se refiere específicamente la Convención son de por sí graves, nos quedamos con el supuesto b), la aplicación de la Convención se refiere a delitos graves de carácter transnacional y que entrañe la participación de un grupo delictivo organizado.

El epígrafe 2 del art. 3 de la Convención define concretamente el delito transnacional:

2. A los efectos del párrafo 1 del presente artículo, el delito será de carácter transnacional si: 
a) Se comete en más de un Estado;

b) Se comete dentro de un solo Estado pero una parte sustancial de su preparación, planificación, dirección o control se realiza en otro Estado;

c) Se comete dentro de un solo Estado pero entraña la participación de un grupo delictivo organizado que realiza actividades delictivas en más de un Estado; 0

d Se comete en un solo Estado pero tiene efectos sustanciales en otro Estado.

Lo primero que debe advertirse es que las reglas establecidas siguen ancladas en la idea de Estado, soberanía nacional, aplicación territorial de la ley penal en los límites estatales, es decir, en concepciones decimonónicas ciertamente superadas en la realidad por la fenomenología de actuación de las redes criminales actuales. Si hacemos una interpretación sistemática con el art. 4, de protección de la soberanía, donde expresamente se resalta el principio de no injerencia, haciendo especial mención de los conceptos clásicos antes referidos, podemos colegir que las reglas del art. 3.2 de delito transnacional parten del reconocimiento de la soberanía de los Estados y el reconocimiento del principio de territorialidad de la ley penal y muy tímidamente establece disposiciones para regular supuestos en los que los delitos trascienden las fronteras nacionales (cross border crimes).

Asimismo, el art. 3.2 de la Convención se inspira en una visión causalista e individualista del delito. Las palabras "comete", ."efectos del delito", denotan una concepción del delito transnacional en el que hay una acción en un Estado y los resultados pueden realizarse en otro Estado, olvidando que precisamente la criminalidad organizada, siendo una forma de cometer delitos a través de organizaciones criminales, expresan algo más que "cometer", expresan estructura, actividad organizativa, reparto de roles, programa criminal, realización sistemática de los delitos (delincuencia profesional), estabilidad, pluralidad de personas (que pueden estar situadas en distintos países), vincularse con distintas personas de dentro o fuera de la organización, donde la causalidad y la visión de la responsabilidad centrada en individuos ha sido superada. Como decíamos "se suele ver las partes, pero no el todo". Al respecto Aleo recuerda, que la organización es una categoría de la complejidad, y la complejidad organizada nos remite a la teoría de sistemas: "el sistema puede ser definido como un complejo (permanente) de dinámicas y, por tanto, de actividades coordinadas, un complejo de relaciones funcionales" ${ }^{\prime 67}$. En los

67 Alé, S., "Criminalità transnazionale e definizione della criminalità organizzata: il requisito dell'organizzazione, cit., pág. 12. También LampE, J. "Systemunrecht und Unrechetsystem", ZStW, 106, 1994. Hay traducción castellana, "Injusto del sistema y sistemas de injusto", en del mismo, La dogmática jurídico-penal entre la ontología social y el funcionalismo, Lima, Grigley, 2003, sostiene que estamos ante injustos de sistema, en la criminalidad estatal, la criminalidad organizada y la criminalidad empresarial. En estos casos "la totalidad del hecho se encuentra en una única relación sistémica, las causas y la responsabilidad se entremezclan entre sí formando una 'red’" (pág. 102). 
sistemas y en las organizaciones, el complejo de las relaciones son dinámicas, por tanto queda superada la causalidad y se erige el concepto de función (fundamental en el análisis de la complejidad). Siguiendo al mismo autor, puede afirmarse que "frente a la noción de causa, la de función no implica la idea de condicio sine qua non, sino de influencia, de utilidad, de contribución y es expresión de un análisis más rico, de tipo multifactorial y contextual"68. Hace ya tiempo que el Derecho Penal ha superado la noción de causalidad para reconocer la noción de función, pero ello no ha llegado a la definición de criminalidad organizada transnacional, según la Convención.

Pasaré a analizar los supuestos concretos, pero antes parece necesario interpretar el verbo "cometer" que aparece en todos los supuestos. Además de poseer una impronta causalista e individualista como ya se ha dicho, en Derecho Penal se puede interpretar como la realización del hecho típico antijurídico, tanto en sus formas activas, omisivas, en cualquiera de sus fases (actos preparatorios, tentativa y consumación). Ahora bien, precisamente los tipos de organización criminal (delitos asociativos -según la doctrina italiana- 0, plurisubjetivos|6 ${ }^{69}$, que como se ha dicho están en la base de la criminalidad organizada transnacional, pertenecen a otra formulación jurídico-penal caracterizada por castigar la propia conducta de asociación criminal independientemente de los delitos cometidos, donde el injusto descansa en la existencia de una estructura preparada para delinquir (realizar el programa criminal), en el que el núcleo de lo injusto está precisamente en la realidad criminógena de la existencia de medios materiales y personales (estructura) idóneos para realizar delitos graves ${ }^{70}$. El requisito de la permanencia ha sido considerado como definidor precisamente de la distinción de los tipos de organización criminal y las figuras tradicionales de coautoría y conspiración. También se trata de un mínimo, que conjuntamente con la estructura, marcan el inicio de la intervención legítima penal, lejos de los modelos anglosajones de la conspiracy que castigan el mero acuerdo ${ }^{71}$.

68 Aleo, "Criminalità transnazionale e definizione della criminalità organizzata: il requisito dell'organizzazione, cit., pág. 13.

69 Por supuesto hay muchas fórmulas en el Derecho Comparado, desde los tradicionales delitos de asociación para delinquir, hasta los modernos delitos de organización criminal. En todo caso, la figura jurídica común, según la Convención de Palermo, es el delito de participación en grupo delictivo organizado. Sobre los diversos modelos de regulación Vid. MııтeцLo, V., “I nuovi modelli di incriminazione delle organizzacioni criminali all'interno dell'Unione Europea", en AA. VV., Scritti in onore di Alfonso M. Stile, Nápoles, Editoriali Scientici, 2013, págs. 5-14.

70 Vid. más ampliamente ZúñIGa Rodríguez, Criminalidad organizada y sistema del Derecho Penal, cit., págs. 269-278, donde desarrollo los requisitos de un injusto de organización criminal.

71 Por supuesto que estos requisitos de permanencia y estructura adolecen de cierta indeterminación. Como advierte Mııтtelıo, "I nuovi modelli di incriminazione delle organizzacioni criminali all' interno dell'Unione Europea", cit., págs. 19-20, la gradualidad del factor temporal puede determinar una 
a) Se comete en más de un Estado.

Para que un delito se cometa en más de un Estado, necesariamente tiene que tratarse de supuestos en los que el delito se estructura en un proceso (escalonada o fragmentadamente) en el que intervienen varias personas, que actúen coordinadamente (aunque sea de manera flexible), en suma, una organización (al menos un grupo estructurado - concepto débill. Vemos dos elementos: fenómenos delictivos que por su naturaleza se estructuran como un proceso que abarca la realización de actividades en varios países, como son los diversos tráficos ilícitos ${ }^{72}$ y, organización o grupo criminal para llevarlos a cabo.

b) Se comete dentro de un solo Estado pero una parte sustancial de su preparación, planificación, dirección o control se realiza en otro Estado.

En este supuesto se hace referencia a la realización de actos preparatorios en un Estado y la consumación del delito en otro Estado. Lo que da relevancia transnacional a este supuesto es que la dinámica comisiva recorre las fronteras de más de un Estado. Es lo que sucedió con los atentados del 11 de septiembre de 2001, en los que gran parte de la preparación se realizó en otro Estado, como en España. Nuevamente estamos ante delitos que se perpetran de manera organizada y por tanto requieren de la existencia de una organización criminal. Sin duda es la organización criminal la que da unidad a la perpetración del delito. Ya sea que funcionen con estructuras en red, flexibles, en compartimentos estancos (modelo Al Kaeda), lo cierto es que existen medios materiales y personales con cierta permanencia aptas para perpetrar delitos.

c) Se comete dentro de un solo Estado pero entraña la participación de un grupo delictivo organizado que realiza actividades delictivas en más de un Estado.

Se trata de la existencia de un grupo delictivo organizado que realiza actividades criminales de carácter internacional, esto es que traspasa las fronteras de más de

incerteza del nivel mínimo de existencia del grupo. Por tanto, el intérprete tendrá que contar con otros factores a la vez: cantidad de medios materiales y personales, entre otros.

72 Paradigmático es el supuesto del tráfico de drogas que, debido a que la oferta se produce desde unos países y la demanda en otros, necesariamente se realiza de manera transnacional. Cfr. sobre la relevancia de este análisis para la ciencia penal: Mııтelıo, V., "Profili penali e problema politicocriminali dell'intervento multilivello sugli stupefacenti. Un confronto fra Italia, Spagna e Unione Europea", en Rivista Trimestrale di Diritto penale dell'economia, № 1, 2014, pág. 95: ". . la tradicional rigidez de los sistemas penales estatales bien pronto ha revelado su ineficacia para enfrentar un fenómeno así estructurado, requiriendo más bien formas avanzadas de cooperación judicial interestatal y un proceso de armonización normativa que le sirva de soporte". Pero también este análisis puede ser útil también para los diversos tráficos ilícitos: de personas, órganos, vehículos robados, diversas tratas, etc. 
un Estado. Aunque la disposición no establece qué tipo de actividades delictivas han de ser, el concepto de grupo delictivo organizado sí presupone la perpetración de delitos graves (penas privativas de libertad de más de 4 años), o los que señala la Convención (participación en organización criminal, lavado del producto del delito, corrupción y obstrucción a la justicia), al menos. Nuevamente en el núcleo de la actividad delictiva transnacional encontramos el grupo delictivo organizado (u, organización criminal).

d) Se comete en un solo Estado pero tiene efectos sustanciales en otro Estado.

Nuevamente el verbo "cometer" ha de entenderse como una realización dinámica de fenómenos criminales, lo cual desde el punto de vista jurídico-penal significa la realización típica de uno o más delitos, cuyos "efectos sustanciales" han de producirse en otro Estado. La alusión a "efectos sustanciales" no puede ser entendida más que los resultados de los delitos, la lesividad de la conducta, la lesión de bienes jurídicos (harm princip). Por tanto, las víctimas han de ser de otro Estado distinto a aquél en que se cometieron las actividades criminales. La disposición utiliza el adjetivo "sustanciales" para señalar la relevancia de los resultados lesivos, no bastando entonces con unos daños simples, sino de entidad importante.

Los cuatro supuestos contemplados reúnen las características que el concepto criminológico de criminalidad organizada transnacional denota: fenómenos criminales que trascienden las fronteras, trasgreden las leyes penales de varios Estados y/o que tengan impacto en otros Estados ${ }^{73}$. En estos casos resultan comprometidas las leyes nacionales de dos o más Estados y, por tanto, tienen trascendencia más allá de los Estados nacionales. La relevancia de estos fenómenos criminales, esto es, su dañosidad social, está precisamente en suscitar efectos jurídicos, sociales y económicos en más de un Estado. Como sostiene Boister, "la delincuencia transnacional describe conductas que tienen efectos transfronterizos reales o potenciales más allá de las fronteras nacionales y puede dar lugar a una preocupación internacional"74.

Pese a las limitaciones antes señaladas del significado causalista e individualista de las reglas del art. 3.2 de la Convención de Palermo, lo cierto es que realmente es un avance respecto a la nada. Además, hay que tener en cuenta las dificultades de llegar a acuerdos ante realidades nacionales tan disímiles. Por tanto, constituye, al menos, un marco jurídico mínimo, que ha de trasponerse en las legislaciones nacionales para que no existan paraísos legales donde puedan refugiarse las organizaciones criminales.

73 Cfr. Boıster, "Transnational criminal law?", cit.,pág. 954.

74 Ibidem. 
También el art. 15 de la Convención de Palermo que establece la competencia de jurisdicciones llena de contenido el concepto de criminalidad organizada transnacional, en la medida que se trata también de un concepto cuya función más importante es evitar la impunidad, lagunas de perseguibilidad o, que los Estados firmantes no se conviertan en paraísos para la delincuencia de carácter transnacional. El principio audedere aut judicare, extraditar o juzgar, es una máxima que impregna la necesidad de que en casos de delitos transnacionales se resuelva la competencia de manera que los hechos no queden en la impunidad. Los Estados solo están dispuestos a asumir jurisdicción de delitos transnacionales cuando hay un "vínculo genuino" entre el Estado y el delito75, por eso entre las características de delito transnacional se acentúa el hecho de que debe existir efectos, daños, perjuicios, víctimas (harm principle) en varios Estados.

En síntesis en el núcleo de la criminalidad organizada transnacional encontramos dos elementos fundamentales: delitos graves (que por su fenomenología se estructuran fragmentadamente) y un grupo criminal organizado (organización criminal). La reiteración del concepto de grupo criminal organizado (el concepto fuerte) en las disposiciones antes referidas, además del principio de fragmentariedad, nos conduce a interpretar que ante un grupo criminal (concepto débil) no podremos considerar la figura de criminalidad organizada transnacional. En suma, cuando nos referimos a la criminalidad organizada transnacional tenemos que pensar en organizaciones criminales, con estructura desarrollada, cierta permanencia, capaces de traspasar las fronteras de los Estados. Un grupo criminal, con estructura poco desarrollada, no tendría la idoneidad para realizar comportamientos criminales que trascienden fronteras. Sobre esto me extenderé en el epígrafe V.7.

\subsection{La Unión Europea y la Decisión Marco de 2008}

Desde los primeros tratados de creación de la UE, como es lógico, se ha considerado de suma relevancia la lucha contra las formas de criminalidad transfronteriza más graves. Las reticencias a ceder soberanía nacional en las competencias penales y el derecho a la no injerencia de los Estados ha sido un lastre para llegar a acuerdos sobre la criminalidad organizada transnacional. Las diversas tipificaciones penales, el diverso nivel sancionatorio, las tradiciones jurídicas distintas y, especialmente, el sistema de garantías que precede la intervención penal, no obstante, no ha impedido que poco a poco se haya avanzado en armonizar algunas figuras fundamentales para la Política Criminal de la UE, mediante el sistema

75 BoIster, "Transnational criminal law?", cit., pág. 964. 
primero de Directivas y luego de Decisiones Marco.

Sin duda, los avances en la creación de un espacio de libertad, seguridad y justicia en la UE (art. 3 TUE) pasa por un acercamiento de la normativa sobre la delincuencia grave transfronteriza entre los Estados. Asílo ha hecho en las propuestas de regulación de determinadas materias que conciernen a todos los Estados de la UE, como las Directivas y Decisiones Marcos sobre falsificación del euro DM 2000/383 del 29.5.2000, terrorismo DM 2002/475 del 13.6.2002, trata de seres humanos DM 2002/629 del 19.6.2002, represión del favorecimiento del ingreso, tránsito y permanencia ilegales DM 2002/946 del 28.11.2002, corrupción privada DM 2003/568 del 22.7.2003, explotación sexual de niños y pornografía infantil DM 2004/757 del 25.10.2004, ataques a los sistemas informáticos DM 2005/222 del 4.2.2005, racismo y xenofobia DM 2008/913 del 28.11.2008, antireciclaje Directiva 2005/60/CE del 26.10.2005, tutela penal del ambiente Directiva 2008/99/CE del 19.11.2008, entre las más destacadas.

Como nos recuerda el Profesor Militello, en los últimos diez años, las competencias europeas en materia penal han experimentado una ampliación progresiva: la armonización directa con respecto a las incriminaciones y a las penas en el Tratado de Lisboa ha sido ampliada a diez sectores de criminalidad particularmente graves que presentan una dimensión transnacional (art. 83.1 co.2 TFUE): terrorismo, trata de seres humanos, explotación sexual de mujeres y niños, tráfico ilícito de drogas, tráfico ilícito de armas, blanqueo de capitales, corrupción, falsificación de medios de pago, delincuencia informática y delincuencia organizada. Con razón, el mismo autor señala que ordenar la delincuencia organizada en el último lugar de la lista de delitos, parece olvidar que precisamente la criminalidad organizada constituye uno de los ejemplos de criminalidad grave de carácter transnacional, por excelencia. 0, la interpretación que puede surgir es que constituya una fórmula residual, de cierre, para abarcar cualquier forma de delincuencia que se realice a través de organizaciones criminales, que permita la armonización ${ }^{76}$.

Importante avance en la lucha contra la criminalidad organizada transnacional ha sido la creación de la Europol por mandato también del art. K.3 del Tratado de Maastricht (1992), iniciando sus actividades formalmente el 3 de enero de 1994, en un primer momento como Oficina de drogas, agregándose poco a poco otras

76 Mııtelıo, V., “Criminalidad organizada transnacional y Unión Europea”, texto hallado en la red, págs. 5 y 6. Puede consultarse también en Cahiers de Défense sociale, № 37, 2011-2012, págs. 123 y ss. http://www.defensesociale.org/CAHIERS 2012/Cahiers 2011-2012 PDF.pdfhttp://www. defensesociale.org/CAHIERS_2012/Cahiers_2011-2012_PDF.pdf, Interpretación que el autor critica por permitir una expansión ilegítima de la intervención penal. 
áreas hasta llegar a su configuración actual, Convenio Europol, de 26 de julio de 1995. Su objetivo fundamental (art. 2.1) consiste en mejorar la cooperación policial entre los Estados miembros, para prevenir y luchar contra las formas más graves de delincuencia internacional. El propio art. 2.1 del Convenio considera "formas graves de delincuencia internacional: los delitos cometidos o que puedan cometerse como actividades de terrorismo que atenten contra la vida, la integridad física y la libertad de las personas, así como contra sus bienes, el tráfico ilícito de estupefacientes, las actividades ilícitas de blanqueo de dinero, el tráfico de material nuclear y radiactivo, las redes de inmigración clandestina, la trata de seres humanos y el tráfico de vehículos robados, así como las formas de delincuencias establecidas en el anexo 0 las manifestaciones específicas de la misma". Es de destacar que la Europol desde su primer momento de funcionamiento ha estado necesitada de pautas racionales de actuación frente al debate teórico de la existencia o no de la criminalidad organizada. Así empiezan a trabajar con 11 características definitorias de este fenómeno, siendo unos obligatorios y otros accesorios, pero que denotan una mayor complejidad. La sistematización de estos 11 indicadores ha tenido un gran éxito en la medida que ha sido utilizado en diferentes ámbitos, tanto operativos, como académicos.

En todo caso, en lo que respecta al tratamiento europeo de la delincuencia organizada transnacional, puede señalarse que el punto de arranque ha sido la Acción Común, de 21 de diciembre de 1998, adoptada por el Consejo, sobre la base del art. K3 del Tratado de la UE, relativo a la punibilidad del delito de participación en organización criminal. Esta normativa constituye el primer paso en la armonización de figuras penales, partiendo de una tipificación común de un delito, promovido por la Convención de Palermo y que constituye el supuesto transversal de las formas de actuación de la criminalidad organizada transnacional.

Especial interés para la materia corresponde a la Decisión Marco 2002/584/ JAI del Consejo de 13 de junio de 2002 relativa a la orden de detención europea y a los procedimientos de entrega entre Estados miembros, por el que se suprime los requisitos de la extradición, especialmente el de doble incriminación, según unas determinadas condiciones para siguientes infracciones: terrorismo, trata de seres humanos, corrupción, participación en una organización criminal, falsificación de moneda, homicidio, racismo y xenofobia, violación, tráfico de vehículos robados y fraude, incluido el fraude en detrimento de los intereses financieros comunitarios. La mayoría de ellos son delitos de la criminalidad organizada transnacional.

En la misma línea de reforzar la cooperación judicial en la UE se da la Decisión Marco 2002/187/JAI, del Consejo, de 28 de febrero de 2002, por la que se crea EUROJUST, para reforzar la lucha contra las formas graves de delincuencia, 
siguiendo las propuestas de la Cumbre de Niza de 2000. Se trata de un órgano intergubernamental con representantes de todos los países miembros, fiscal, juez o policía, competente para coordinar las investigaciones y actuaciones (en relación con al menos dos Estados miembros), relativas a las formas graves de delincuencia.

Pero la normativa europea clave sobre el tema es la Decisión Marco 2008/841/ JAI del Consejo de 24 de octubre de 2008, relativa a la lucha contra la delincuencia organizada, que viene a sustituir la Acción Común de 1998 y que se ocupa de la tipificación del delito de participación en organización criminal en su art. 2, la responsabilidad penal de las personas jurídicas en el art. 5 y de los problemas de competencia de los delitos transnacionales en su art. 7, entre los puntos más relevantes. Sin embargo, no contempla ninguna norma sobre la criminalidad organizada transnacional o el carácter transnacional de los delitos, como sí lo hace la Convención de Palermo, simplemente establece unas reglas de competencia y coordinación de actuaciones judiciales en el caso de delitos transfronterizos, haciendo alusión a los mismos en el art. 7.1 a) solamente. Ello es así pese a que en la Exposición de Motivos (6) establece que la finalidad de esta norma es "completar el importante trabajo realizado por los organismo internacionales, en particular por la Convención de Naciones Unidas contra la Delincuencia Organizada Transnacional".

Artículo 7

Competencia y coordinación de las actuaciones judiciales

1. Todos los stados miembros adoptarán las medidas necesarias para establecer su competencia respecto de los delitos a que se refiere el artículo 2 cometidos:

a) total o parcialmente en su territorio, independientemente del lugar en que la organización delictiva tenga su base 0 ejerza sus actividades delictivas;

b) por sus nacionales, 0

c) en beneficio de alguna persona jurídica establecida en el territorio de dicho Estado miembro.

Ahora bien, el art. 1 define la "organización delictiva" y la "asociación estructurada", muy similarmente a las definiciones de la Convención de Palermo de "grupo delictivo organizado" y "grupo estructurado", respectivamente. Mientras que el art 2 sí define más prolijamente el delito de participación en organización criminal, tipificando dos conductas:

A) El que de manera intencionada y a sabiendas de la finalidad y actividad delictiva de la organización, participe activamente en las actividades ilícitas de la organización.

B) El que acuerde con una o más personas realizar actividades del tipo anterior. Aunque en nuestra tradición europea difícilmente quepa legítimamente tipificar 
la conducta B) que se inspira en la conspiracy anglosajona, nos quedamos nuevamente con la idea de que el delito transversal de estas figuras de la criminalidad organizada transnacional es el de participación en organización criminal. Ahora bien, resulta criticable la extensión de la comprensión de participación en organización criminal a comportamientos de mera colaboración, aunque relevante como: "la facilitación de información o de medios materiales, reclutando a nuevos participantes, así como en toda forma de financiación de sus actividades a sabiendas de que su participación contribuirá al logro de la finalidad delictiva de esta organización".

Dos cuestiones resultan de relevancia después de observar el panorama regulativo europeo. Primero, al igual que en la normativa de la Convención de Palermo, el núcleo de las formas de la criminalidad organizada transnacional son la existencia de una organización criminal y la comisión de delitos graves con un despliegue transfronterizo. Hay tres elementos que denotan la gravedad (las dificultades de persecución y tratamiento penal) de los delitos que nos ocupan: organización criminal, delitos graves y transnacionalidad. El común denominador es la gravedad de los delitos, cuestión que merece un acápite propio.

En segundo lugar, llama la atención cómo el dinamismo de la actuación de las formas de delincuencia transnacional ha propiciado primeramente la cooperación policial, luego judicial y en una tercera etapa está el acercamiento normativo. Esto significa algo: normalmente son los aspectos operativos, de persecución penal, los que atraen la armonización legislativa y no al revés. Cuestión interesante para comprender los aspectos a destacar de la criminalidad organizada transnacional. Este aspecto digamos más de índole criminológico, especialmente evidenciado por el protagonismo de los indicadores de Europol, nos muestra que la gravedad material de las actuaciones de las organizaciones criminales que actúan a nivel internacional es un hecho empíricamente demostrable, que alerta a las fuerzas policiales y que en los últimos años ha ido in crescendo ${ }^{77}$.

\section{5 ¿Qué se entiende por delitos graves?}

En el meollo de la criminalidad organizada transnacional encontramos una organización criminal, que realiza delitos graves, con efectos importantes en más de un país, como se ha puesto de manifiesto. En este acápite nos proponemos revisar ¿qué se entiende por delitos graves? A la par, plantear si es la mejor manera de

77 En el año 2013, el 67\% de los grupos criminales detectados presentaba actividad internacional. Según datos del Ministerio del Interior, "Balance de la lucha contra el crimen organizado en España", www.interior.gob.es 
comprender este desvalor de los comportamientos criminales perpetrados por las organizaciones criminales internacionales.

Tanto la Convención de Palermo, como la Decisión Marco de 2008, consideran organización criminal punible aquella que perpetúa delitos graves. A su vez, el ámbito de aplicación de la Convención de Palermo, considera criminalidad organizada transnacional (art. 3.b), aquella que realice delitos graves (considerados..., cuando estos delitos sean de carácter transnacional y entrañen la participación en grupo delictivo organizado. Dado que la definición de grupo delictivo organizado presupone la comisión de delitos graves, ha de entenderse que el carácter transnacional es el plus de gravedad que entraña la realización de actividades en redes internacionales.

Encontramos la gravedad de los delitos en el núcleo de la definición de criminalidad organizada transnacional, lo cual implica darle relevancia a qué se entiende por delitos graves. La asimilación de delitos graves y delitos transnacionales, se colige de toda la normativa internacional y también de la práctica ${ }^{78}$, dado que para realizar delitos que trascienden las fronteras nacionales se requiere un aparato organizado de estructuras personales y materiales coordinado (concepto fuerte de organización criminal). Es decir, todos los delitos transnacionales son necesariamente graves y presuponen una organización criminal que despliega sus efectos en más de un Estado ${ }^{79}$. La UE también suele considerar como delitos especialmente graves los cometidos por la criminalidad organizada de carácter transnacional 0 transfronterizos ${ }^{80}$.

Ahora bien, el carácter grave de los delitos es un concepto indeterminado que posee una relatividad impropia del principio de legalidad que preside las reglas de la tipificación penal. El parámetro de gravedad que se ha seguido internacionalmente desde la Convención de Palermo, delitos con penas o medidas de seguridad no inferior a cuatro años, esconde en la práctica una gran diferencia valorativa, puesto que no existe nada más variado que la escala de penas si la comparamos de un país a otro. Como sostiene Militello, "La referencia a un determinado nivel de pena, es, por tanto, común sólo en valor absoluto, pero mantiene un valor relativo diferenciado según los techos o límites superiores en la pena que la propia jurisdicción internamente

78 Cfr. Mapell / González / Aguado (Coords.), Estudios sobre delincuencia organizada. Medios, instrumentos y estrategias de investigación policial, Sevilla, Mercablum, 2001, pág. 83, donde los estudios de campo policiales muestran que el nivel organizativo de los grupos, dado por el número de miembros y el ámbito territorial de actuación, demuestran el nivel de peligrosidad del grupo.

79 Así lo hace la Ley brasileña Ley № 12.850 de 2 de agosto de 201, art. 1.1, que claramente considera punible la organización criminal que realiza delitos graves o con carácter transnacional.

80 Cfr. Mııтtelıo, “Criminalidad organizada transnacional y Unión Europea”, cit., pág. 3. 
establece" ${ }^{\prime 81}$. Así, por poner un ejemplo, entre dos países cercanos de la UE, como España e Italia y un delito característico de la criminalidad organizada, como lo es el tráfico ilícito de drogas, se puede observar grandes diferencias de penalidad: el art. 368 CP español, establece penas que van de 3-6 años si las drogas "causan grave daño a la salud" y 1-3 años, para los otros casos; mientras que la Ley italiana contra el tráfico de estupefacientes, en su art. 73, establece penas de 8-20 años para drogas duras y 2-6 años para drogas ligeras ${ }^{82}$.

De ahí que últimamente se apueste, como lo hace la Resolución del Parlamento Europeo de 25 de octubre de 2011 sobre la materia, por una lista común mínima de delitos, para llevar a cabo la armonización de las leyes y la cooperación policial y judicial. Pero entonces surge la pregunta ¿qué delitos serían propios de la criminalidad organizada transnacional?

\section{6 ¿Qué delitos específicos pueden ser propios de la criminalidad organizada transnacional?}

El debate sobre establecer una relación concreta de delitos que son objeto de persecución penal en el ámbito de la criminalidad organizada, tradicionalmente se ha saldado con la determinación genérica de la gravedad de los mismos, en orden a que esta forma de criminalidad es muy cambiante y establecer un numerus clausus de delitos conllevaría necesariamente lagunas de punibilidad. Pero vista la indeterminación de la fórmula gravedad del delito, conviene indagar por esa lista de delitos.

En efecto, existen en los códigos penales una serie de delitos que necesariamente se cometen en el ámbito de organizaciones más o menos estructuradas. Y, además, son de carácter internacional en la medida que se trata de tráficos ilícitos de bienes o servicios cuya oferta es de unos Estados y la demanda se produce en otros Estados. Éstos, por su propia fenomenología requieren de organización para su perpetración y estructuras (medios materiales y personales) de carácter transnacional. Digamos que hay delitos que criminológicamente son transnacionales: el tráfico ilícito de drogas, la trata de personas, el tráfico de inmigrantes, los diversos tráficos ilícitos (de armas, de productos radioactivos, de vehículos robados, etc., etc.), el blanqueo de capitales, los delitos cometidos por Internet (red de redes), como pornografía infantil, como los más destacados.

Desde el punto de vista jurídico, un buen punto de referencia son los delitos

\footnotetext{
81 Ibidem, pág. 10.

82 Cfr. Mııtтello, "L’identità della scienza giuridica penale nell'ordinamento multilivello", cit.,págs. 103104.
} 
que establece la propia Convención de Palermo y sus Protocolos. Podría tratarse del núcleo duro de la criminalidad organizada transnacional, puesto que la propia Convención así lo establece. Penalizar en sus ordenamientos jurídicos internos determinadas conductas delictivas: participación en un grupo delictivo organizado (art. 5), blanqueo 0 lavado del producto del delito (arts. 6 y 7), corrupción de funcionarios públicos (art. 8) y la obstrucción de la justicia (art. 23). Así como la trata de personas y el tráfico ilícito de migrantes.

También un buen termómetro de las necesidades de tipificación de delitos propios de la criminalidad organizada transnacionales es tener en cuenta el último Informe del Parlamento Europeo 2009-2014: "el crimen organizado desarrolla dos tipos de actividades: por un lado, las organizaciones criminales se dedican a un gran número de actividades de negocios legítimos, y, por otro lado, tienden a administrar sus actividades ilícitas de manera similar al mundo de los negocios, intercambiando ambos tipos de actividades y los beneficios de ambas" ${ }^{\prime \prime 3}$. Indudablemente los que dan contenido a la actividad criminal de la organización son los negocios ilícitos, pero no siempre es fácil deslindar. En el mundo de la economía global confluyen los intercambios de las organizaciones criminales, tanto de sus actividades lícitas como ilícitas. El mismo Informe considera: "Los delitos típicamente vinculados con el crimen organizado -hasta el punto de constituir su negocio principal- también son gravemente perjudiciales para la sociedad y constituyen una amenaza específica para la supervivencia de las personas honestas de negocios y la seguridad de los consumidores. Éstos incluyen: la extorsión, el chantaje, el daño, hurto, robo, corrupción de políticos y administradores, de autoridades; fraude tarjetas de crédito, la usura, el espionaje industrial, la adquisición ilegal de fondos de la UE; obtención fraudulenta de contratos públicos; falsificación de productos alimenticios, medicamentos, pesticidas, prendas de vestir; el contrabando de cigarrillos, alcohol, joyas, obras de arte; las apuestas ilegales, el amaño de partidos y los juegos de azar, incluyendo en línea; la trata de seres humanos, armas, órganos, drogas, animales en peligro de extinción; vertido ilegal de residuos tóxicos, etc. Todo esto pone en peligro, entre otras cosas, la salud física de los consumidores y la salud socioeconómica del mercado"84.

\subsection{La gravedad de la criminalidad organizada transnacional (la}

83 Parlamento Europeo, Working document on organized crime, cit., pág. 3.

84 Ibidem, pág. 5. 


\section{lesividad de la organización criminal de carácter internacional)}

Nótese que la gravedad de la criminalidad organizada transnacional está señalada por partida doble: por la gravedad de los delitos que realiza, en la medida que afectan a más de un Estado y por la necesaria existencia de una organización criminal, donde el adjetivo "criminal" presupone la realización de delitos graves. Por otro lado, como se ha puesto de manifiesto, el carácter transfronterizo de las actividades delictivas, la capacidad de producir efectos lesivos en más de un Estado, denota una estructura con cierta complejidad. De ahí que los tres términos: delitos graves, grupo delictivo organizado (organización criminal) y transnacionalidad sean tres conceptos que se entrecruzan en el núcleo común de la gravedad, pero observada desde "el todo" de la fenomenología de actuación de organizaciones criminales que realizan actividades que trascienden los Estados nacionales. Ahora cabe una pregunta: iSe trata de una gran organización criminal con proyección internacional? 0 iPuede tratarse también de una red de organizaciones criminales menores que trabajan en escala para un proyecto criminal con proyección internacional?

En España esa cuestión se ha resuelto respecto a la interpretación de la consideración de extrema gravedad del delito de tráfico de drogas (art. $370.3^{\circ} \mathrm{CP}$ ), cuando se realiza a través de redes internacionales, de acuerdo a lo dispuesto por la Circular 2/2005 de la Fiscalía General del Estado, requiriendo que las actividades de los grupos criminales deban tener proyección internacional, esto es, dentro de su programa criminal esté la realización de delitos transnacionales. Como apunta Méndez Rodríguez, puede tratarse de varias organizaciones criminales autónomas, asentadas en distintos países, que actúan en red para la comisión conjunta de tráfico internacional de drogas, o una gran organización criminal de carácter internacional, con una única dirección, dedicada al tráfico de drogas ${ }^{85}$. No cabría aplicar la agravación por el solo hecho de que una parte del proceso se produzca en un país y otra parte en otro, como sucede con el cultivo, proceso y distribución de drogas.

Traducida esta reflexión a nuestro objeto, el significado de criminalidad organizada transnacional, se diría que es importante identificar la entidad de la/s organizaciones criminal/es que pueden considerarse transnacionales, esto es, con la aptitud de tener efectos (importantes) en más de un Estado. En el ámbito criminológico, como se ha puesto de relieve, suelen existir un sin número de personas, grupos, organizaciones, profesionales, empresas que intervienen en la realización de un delito de carácter transnacional, como por ejemplo, el tráfico internacional de drogas, tanto porque se

85 Méndez Rodríguez, "Los delitos de pertenencia a organización criminal y grupo criminal y el delito de tráfico de drogas cometido por persona que pertenece a una organización delictiva", cit., pág. 547. 
trata de fenómenos criminales que se realizan en varias fases (es todo un proceso), como porque necesariamente está fragmentada la oferta y la demanda entre unos países y otros. Ahora bien, ¿toda aportación, personal o de grupo, ha de considerarse como "parte" del "todo" criminalidad organizada transnacional? Afirmar esto sería prácticamente admitir una responsabilidad objetiva, inadmisible, por el solo hecho de realizar una parte del proceso criminal internacional. Pero por otro lado, requerir que en todo comportamiento haya proyección internacional es condenar el concepto de criminalidad organizada transnacional al fracaso, en la medida que es prácticamente imposible comprobar esa finalidad prácticamente subjetiva. Nuevamente no se puede tomar "las partes" por el "todo", ni el "todo" por las "partes".

Para dar una respuesta matizada creo que es preciso preguntarnos por la lesividad de las organizaciones criminales de carácter internacional, la aptitud 0 idoneidad para afectar bienes jurídicos de varios países. Para ello hay que establecer la importancia de los bienes jurídicos en juego y el grado de amenaza para los mismos. Hemos señalado que los Estados solo están dispuestos a asumir jurisdicción de delitos transnacionales cuando hay un "vínculo genuino" entre el Estado y el delito, esto es hay una lesión directa a intereses nacionales (bienes jurídicos), por eso en las características de delito transnacional se acentúa el hecho de que debe existir efectos, daños, perjuicios, víctimas (harm principle) en varios Estados (art. 3 Convención de Palermo). Es coincidente esta regla tanto en el common law como en el sistema eurocontinental. Ahora bien, determinar intereses comunes entre varios Estados no siempre es tarea fácil, menos aún la existencia de una Civitas máxima (ideal kantiano), porque no existe una Comunidad Internacional o un Orden Internacional claramente reconocido ${ }^{86}$, al cual se puede establecer como amenaza la actuación de organizaciones criminales de la criminalidad organizada. Bastaría con la necesidad de cooperación (principio de solidaridad entre los pueblos), para perseguir comportamientos nocivos con efectos importantes en varios Estados.

Por tanto, el principio de subsidiariedad y de fragmentariedad nos obliga a una interpretación restrictiva en el sentido de establecer que serán entendidas como organizaciones criminales de carácter transnacional tanto una macro-organización criminal internacional, como una red de organizaciones criminales con actividad internacional, siempre que sean funcionales para la realización del programa criminal de carácter internacional. El concepto de grupo criminal organizado presente en el art. 3

86 Cfr. Boıster, "Transnational criminal law?", cit., pág. 970, para quien sí sería un reconocimiento de unos bienes jurídicos supraindividuales de orden superior, la firma del Tratado de Roma, el Estatuto de la Corte Penal Internacional. Precisamente lo que distingue el Derecho Penal Internacional del Derecho Penal Transnacional. 
de la Convención de Palermo, delitos graves, intereses importantes afectados en varios países, denotan estructuras (únicas, en red, flexibles, jerárquicas) que tengan cierta complejidad como para ser capaz de trascender las fronteras. Los grupos criminales (concepto débil) con expansión territorial limitada, estarían fuera del significado criminalidad organizada transnacional, salvo que pertenezcan a una red y realicen actividades criminales funcionales al programa criminal de carácter transnacional.

Como se trata de una serie de hipotéticas posibilidades, lo importante es determinar la existencia de estructuras personales (organización única/redes) y materiales (medios) con un programa criminal de carácter internacional, capaz de lesionar intereses importantes de varios Estados. Lo determinante es establecer la funcionalidad de las intervenciones personales y organizacionales. Por eso, en este ámbito será muy importante la motivación de las sentencias, la explicación argumentativa tanto de su pertenencia o no pertenencia a la criminalidad organizada transnacional.

\subsection{Participación en organización criminal, responsabilidad penal de las personas jurídicas, non bis in ídem y garantías}

Para cerrar los problemas que pueden plantear una concepción de criminalidad organizada transnacional, me referiré a otros aspectos relevantes que deben ser atendidos. Aunque cada problema podría dar lugar a un tratamiento específico y detallado, por tanto merecería un tratamiento monográfico, se abordarán los aspectos más destacables, dado que no es posible agotarlos en el espacio de este trabajo.

Primera cuestión: la falta de alusión al problema de la responsabilidad penal personal por parte de la Convención.

Centonze destaca este aspecto llamando la atención sobre la omisión de la Convención a alguna referencia sobre los parámetros de responsabilidad requeridos en los delitos cometidos con carácter transnacional ${ }^{87}$. En realidad este es un aspecto demasiado complicado y heterogéneo como para llegar acuerdos, y por ello quizá se obvió este tema. En efecto, como apunta Boister, el Derecho Penal Transnacional ha prestado poca atención al ámbito de la responsabilidad penal, grados de participación, requisitos de la responsabilidad (elementos de culpa, dolo, etc. ${ }^{88}$. El delito de participación en organización criminal pretende dar respuestas a esta cuestión. Pero, como enseguida se verá, "participación en" resulta un término

87 Centonze, Criminalità organizzata e reati transnazionali, cit., pág. 169.

88 BoIster, "Transnational criminal law?", cit., pág. 958, para quien es precisamente una de las debilidades del desarrollo de la Política Criminal transnacional. 
jurídico tan indeterminado que pueden abarcar muy diversas conductas.

¿Qué se entiende por participación en organización criminal? Normalmente se entiende a quienes forman parte de su estructura (permanente), son integrantes de la sociedad en la medida que hacen común el programa criminal, se reparten las tareas para un fin común, es decir, quienes forman parte de la sociedad criminal. Se consideran así a los integrantes, miembros activos de la organización, todo aquel que posee un rol en la realización del programa criminal. Pero a partir de esta consideración hay una serie de comportamientos de diferente índole y, por tanto, de mayor o menor grado de responsabilidad. Así, los fundadores, los dirigentes, suelen considerarse de mayor responsabilidad que un integrante de menor jerarquía, en la medida que son quienes toman las decisiones criminales y, luego, en organizaciones jerárquicas puede haber distinto grado de responsabilidad, según se va bajando en la escala jerárquica. Por otro lado, se entiende "adyacentes" a la organización los comportamientos de quienes colaboran con la organización criminal (actos de colaboración), pero sin formar parte de la misma. Pero aquí también puede tratarse de colaboraciones accesorias, puntuales (comportamientos neutrales) o comportamientos sustanciales para la existencia de la organización 0 para la realización de su actividad delictiva, como los que realizan los profesionales (White collar crime) que asesoran a las organizaciones criminales para blanquear las ganancias ilícitas, cuyos conocimientos son tan relevantes y sus colaboraciones tan sustanciales, que últimamente preocupan a los organismos internacionales.

Efectivamente, especial relevancia para el momento actual tiene la determinación de la responsabilidad penal de las conductas de los profesionales "adyacentes" de las organizaciones criminales. En la medida que las organizaciones criminales actuales se han infiltrado en la economía con inversiones lícitas, que utilizan a profesionales para el asesoramiento del lavado de dinero, la ocultación de sus activos ilícitos, preocupa la respuesta penal para estas conductas, muchas aceptadas socialmente 0 en los límites de la ilegalidad. Se trata, en muchos casos, de profesionales (abogados, notarios, contables, asesores financieros, etc.) que realizan colaboraciones relevantes para la perpetración de las actividades de la organización. Afinar las reglas para la determinación de la responsabilidad penal de estos profesionales es una tarea actual pendiente de la Política Criminal moderna.

Segunda cuestión: la responsabilidad penal de las personas jurídicas y delitos transnacionales.

La construcción persona jurídica ha servido históricamente para diversificar riesgos y responsabilidades. De ello se ha aprovechado la criminalidad organizada para diversificar sus negocios, invirtiendo en negocios lícitos e ilícitos. La consideración 
de empresa criminal que proviene de la Ley Rico deja entrever cómo la figura persona jurídica (corporate crime) es tremendamente maleable para ocultar dinero ilícito proveniente del crimen organizado (organized crime), reciclar dinero y, en suma, para ocultar actividades ilícitas. Es por eso que los Convenios Internacionales, como la Convención de Palermo y las Decisiones Marco correspondientes han recomendado regular en las legislaciones internas la responsabilidad penal de las personas jurídicas vinculadas con la criminalidad organizada. Podría decirse que, cuando se trata de criminalidad organizada transnacional el asunto se vuelve aún más acuciante porque la comparativa de las legislaciones puede favorecer la constitución de sociedades en paraísos legales, o donde los controles son poco rígidos.

Hace un buen tiempo que la lucha contra las organizaciones criminales se centra en estrangular el ciclo económico del dinero ilícito, esto es, de perseguir el patrimonio criminal a través de las personas jurídicas, sociedades, el comiso de las ganancias, la recuperación de activos de las organizaciones criminales. Hoy en día, la diversificación de los negocios de las organizaciones criminales internacionales ha conllevado también la internacionalización de sus empresas y de la fórmula persona jurídica para sortear leyes, tributos y mandatos. Hay que tener en cuenta que muchas veces no es nítida la línea divisoria entre organización criminal y persona jurídica, por lo que las regulaciones internas han de prever una normativa idónea, siendo entre otros problemas la cuestión de la determinación de los tipos penales por los que responden las personas jurídicas (numerus clausus) una cuestión a atender ${ }^{89}$.

En la legislación española se prevé una especial agravación (extrema gravedad), art. $370,3^{\circ} \mathrm{CP}$, cuando las conductas de tráfico de drogas se hayan llevado cabo simulando operaciones de comercio internacional entre empresas, pues su persecución penal resulta más dificultosa y denota una mayor complejidad de la operación. Ahora bien, esta previsión no se ha hecho para otros delitos de la criminalidad organizada transnacional, que podría ser relevante como para el blanqueo de capitales, entre otros. Por lo que sería más conveniente una previsión general, no en la Parte Especial.

Tercera cuestión y no por ello menos importante: el problema del non bis in ídem y las garantías.

La complejidad que alumbra este tema, hace que en muchos casos pueda ocasionarse una doble incriminación incluso en un mismo país o sobre-agravaciones claramente conculcatorias del principio non bis in ídem, como agravaciones espe-

89 En diciembre de 2012 la Petrolera Mexicana PEMEX denunció a las empresas Siemens (Alemania) y SK Engineering and Construction (Korea) por actos fraudulentos e ilegales, al ofrecer sobornos a sus directivos para obtener contratos, argumentando que dichas compañías violaron la Ley RICO. Vid. http://www.cnnexpansion.com/negocios/2012/12/13/pemex-demanda-a-siemens-y-sk-engineering 
cíficas y agravaciones genéricas de reincidencia, habitualidad, pertenencia a organización criminal, participar en redes internacionales, etc. La situación puede ser aún más compleja cuando se trata de distintos niveles de fuentes aplicables en la posible concurrencia de varias leyes penales de distintos países.

Como la criminalidad organizada implica una forma de cometer determinados delitos, de manera concertada a través de una organización estable, en muchos casos nos encontramos con una duplicidad en la tipificación de las conductas 0 , una doble 0 triple agravación que claramente vulnera el principio de lesividad y proporcionalidad, además de constituir claramente una afrenta a una de las vertientes del principio de legalidad, el de non bin in ídem.

El Profesor Militello llama la atención sobre los riesgos que un concepto de criminalidad organizada demasiado amplio en el contexto del art. 31.2 Tue podría conllevar una inútil duplicidad de tipificaciones, en la medida que varios delitos ya han sido regulados en las normas penales ${ }^{90}$. En efecto, la coordinación de los tipos penales de organización con los delitos que comete la organización presenta problemas desde la etapa legislativa, así como en la aplicación jurisprudencial, cuestión debida a que la tipificación de los delitos que comete la organización criminal responde a la pregunta del ¿qué?, y lo relativo a los delitos de organización a la pregunta del ¿cómo?, cuestión ésta que a nuestro entender debe regularse en la Parte General, no en la Parte Especial, por tratarse de una forma de realización de los delitos por medio de organización ${ }^{91}$.

Por eso la resolución de los concursos del delito de participación en organización criminal y los delitos específicos se convierte en una tarea ardua y compleja, muchas veces con soluciones impropias e injustas ${ }^{92}$, dado que normalmente las tipificaciones penales no han seguido una lógica sistemática, sino que se han ido superponiendo reforma tras reforma, sin buscar una coherencia interna. Precisamente, para ordenar estos diversos ilícitos se propone regular un tipo de organización criminal en la Parte General y una forma agravada por el carácter

90 Cfr. Mıııtello, “Criminalidad organizada transnacional y Unión Europea”, cit., pág. 6.

91 Vid. más ampliamente ZúÑIGa Rodríguez, Criminalidad organizada y sistema del Derecho Penal, cit., págs. 262 y ss. donde explico los fundamentos de un injusto de organización, distinto al injusto personal, con una materia de prohibición propia, un injusto de peligrosidad que debe constatarse exante y, por tanto, regularse en una regla general de la Parte General.

92 Cfr. Méndez Rodríguez, C., "Los delitos de pertenencia a organización criminal y grupo criminal y el delito de tráfico de drogas cometido por persona que pertenece a una organización delictiva", cit., pág. 549 y ss., trabajo que muestra las sobreagravaciones e incoherencias respecto al delito tráfico de drogas, cuando se trata de redes internacionales. 
transnacional del delito.

Pero cuando hablamos de criminalidad organizada transnacional no solo puede vulnerarse el principio de non bis in ídem, sino que precisamente uno de los problemas más acuciantes es el posible déficit de garantías existente, tanto en los Convenios Internacionales como en los procesos de armonización, al compararlo 0 trasponer en las legislaciones nacionales. Desde las clásicas críticas de tipos intedeterminados que preside la tipificación de los tipos de organización, a las técnicas de investigación consideradas idóneas para estas formas de criminalidad (escuchas telefónicas, agentes encubiertos, entregas vigiladas, etc.), lo cierto es que nos encontramos con reglas distintas de intervención, con diferentes niveles de exigencias en lo que respecta al respeto de los derechos humanos ${ }^{93}$. Ante esta debilidad de las normas internacionales que regulan la criminalidad organizada transnacional es preciso observar, como aprecia Militello, que no se trata de anhelar un retorno al modelo de derecho penal clásico, limitado a las formas tradicionales de ofensa, sino por el contrario, el derecho penal debe responder a la complejidad de la modernidad, con la apertura a otras formas de conocimiento, convenientes según los fenómenos sociales ${ }^{94}$. Concretamente en el ámbito de la UE, se trata de repensar las garantías tradicionales en la dimensión europea, esto es, tener en cuenta las decisiones del Tribunal Europeo de Derechos Humanos en la materia y la Carta Europea de Derechos Humanos, en tanto mínimo-común exigible en el respeto a los derechos humanos ${ }^{95}$.

\section{Conclusiones: Conjugando el todo y las partes (el significado de criminalidad organizada transnacional)}

Después de esta revisión de los problemas que plantea establecer lo que la etiqueta criminalidad organizada plantea, vemos que es importante:

1. Más que establecer un concepto de criminalidad organizada transnacional, muy difícil dada la necesidad de abarcar comportamientos bastante heterogéneos, de distintos países con tradiciones jurídicas propias, se trata de establecer un acuerdo de mínimos o, en todo caso, un concepto funcional para mejorar el abordaje jurídico

93 Sobre esto llaman la atención: BoISTER, cit., pág. 958, por lo cual se produce una interna resistencia de los Estados nacionales. Mııtтello, "Criminalidad organizada transnacional y Unión Europea”, cit., pág. 1, quien plantea como primera dificultad de la armonización de las legislaciones penales en la UE, el respeto de los tradicionales principios de los sistemas penales nacionales.

94 MııтeцLo, "L’identità della scienza giuridica penale nell’ordinamento multilivello", cit., pág. 108.

95 MııтeцLo, “Criminalidad organizada transnacional y Unión Europea", cit., pág. 2. 
y político-criminal del fenómeno (armonización y cooperación policial y judicial).

2. En la clasificación de lo que es criminalidad organizada transnacional hay que distinguir los delitos transnacionales de los delitos internacionales, abarcando los primeros aquellos que se caracterizan por su fenomenología de actuación transfronteriza, y por tanto, por su capacidad para vulnerar las leyes y provocar perjuicios (víctimas / resultados lesivos) en más de un Estado.

3. El concepto criminológico de criminalidad organizada que se ha impuesto en la Convención de Palermo y ha servido de modelo a los demás países, nos muestra que se trata de una fenomenología de actuación dinámica a través de organizaciones criminales / no criminales, que presuponen la existencia de una organización criminal 0 más (grupo fuertemente estructurado de personas), con cierta complejidad (desarrollada, desechándose el concepto débil de "grupo estructurado" o "grupo criminal"), capaz de transportar bienes, servicios o personas de un país a otro.

4. Tanto la organización criminal, como la transnacionalidad de su actuación denota un plus de gravedad respecto de una organización criminal común. Por tanto, ha de ser importante llenar de contenido qué se entiende por delitos graves, valoración que hasta la fecha ha resultado estéril por tratarse de una comparación relativa, planteándose más bien la necesidad de establecer una lista de delitos propios de la criminalidad organizada transnacional. Asimismo, las normas penales deben prever una agravación cuando se trata de delitos de la criminalidad organizada transnacional, respecto de los tipos simples de organización criminal. Todo ello en regulaciones de la Parte General y no en cada delito como suele regularse.

5. El significado de criminalidad organizada transnacional nos lleva a la cuestión de establecer la entidad de las organizaciones criminales que la componen: lesividad. Lo importante es determinar la existencia de estructuras personales (organización única / redes) y materiales (medios) con un programa criminal de carácter internacional, idóneas para lesionar intereses importantes de varios Estados. Lo determinante es establecer la funcionalidad de las intervenciones personales y organizacionales. Por eso, en este ámbito será muy importante la motivación de las sentencias, la explicación argumentativa tanto de la pertenencia o no pertenencia a la criminalidad organizada transnacional.

6. La persecución de una organización criminal internacional puede plantear problemas de non bis in ídem (doble penalización o doble agravación), entre otros déficits de garantías, generalización de la responsabilidad penal (tomar el todo por las partes), diferencias notables en la individualización de la responsabilidad, y el uso y abuso de personas jurídicas para la perpetuación de los delitos.

\section{Bibliografía}


Aguado, T., "Decomiso de los productos del delito en la delincuencia organizada, Garantizar que el delito no resulte provechoso", Revista electrónica de Ciencia Penal y Criminología, № 15-05, 2013.

Ambos, K., "Sobre 'la organización' en el dominio de la organización", en Indret, N³, 2011.

Aleo, S., Sistema penale e criminalità organizzata. Le figure delittose associative, Milán, Giuffré, 1999, pág. 6.

Aleo, S. "Criminalità transnazionale e definizione della criminalità organizzata: il requisito dell'organizzazione", en Nuove strategie per la lotta al crimine organizzato transnazionale, Turín, Giappichelli, 2003, pág. 10.

Bandinı / Lagazzı / Marugo /, La Criminalità Organizzata. Moderne metodologie di ricerca e nuove ipotesi esplicative, Milán, Giuffrè, 1993, pág. 180.

Berdugo Gómez de la Torre, I., "Acerca de la internacionalización del Derecho Penal", en Pérez Cepeda (Dir.), El principio de justicia universal: fundamento y límites, Valencia, Tirant lo Blanch, 2012, pág. 22.

Boıster, N. Transnational criminal law, Vol. 14, No. 5, 2003, pág. 956.

Bassiouni / Vetere, Organized Crime. A Compilation of U. N. Documents 1975-1998, New York, ONU, 1998, cit., pág. XVII y Vid. un extracto del documento en, el mismo, págs. 812-815.

Caciagu, M., Clientelismo, corrupción y criminalidad organizada, Madrid, Centro de Estudios Judiciales, 1996, págs. 10-11.

Centonze, A., Criminalità organizzata e reati transnazionali, Milán, Giuffrè, 2008, pág. 167.

FerRé Olivé, J.C., "Una nueva trilogía en Derecho penal tributario: fraude, regularización y blanqueo de capitales", en Revista de contabilidad y tributación, № 372, 2014, págs. 44 y ss.

Ferrajolı, L., Derechos y garantías. La ley del más débil, Madrid, Trotta, 1999, págs. 116 y ss.

Ferrí Olivé / Anarte (Eds.), Delincuencia organizada. Aspectos penales, procesales y criminológicos, Univ. de Huelva / Fundación El Monte, 1999, pág. 178.

Gónzález Alonso, B., El Todo y las Partes. Una aproximación jurídico-institucional al proceso de formación de España y de su organización territorial, Universidad de Salamanca, 2014.

GutiérRez Francés, M., “Las altas tecnologías de la información al servicio del blanqueo 
de capitales transnacionales", Aquilafuente, N0 38, pág. 209.

HeLD, D., Un pacto global. La alternativa socialdemócrata al consenso de Washington, Madrid, Taurus, 2005, págs. 129 y ss.

KIss, A., "La contribución en la comisión de un crimen por un grupo de personas en la jurisprudencia de la Corte Penal Internacional", en Indret, N² 2, 2013.

InNerarity, D., Un mundo de todos y de nadie. Piratas, riesgos y redes en el nuevo desorden global, Barcelona, Paidós, 2013, pág. 18.

Méndez Rodríguez, C., “Delitos objeto del principio de justicia universal: naturaleza y límites", en Pérez Cepeda (Dir.), El principio de justicia universal: fundamento y límites, cit., pág. 326.

Méndez Rodríguez, C., “Los delitos de pertenencia a organización criminal y grupo criminal y el delito de tráfico de drogas cometido por persona que pertenece a una organización delictiva. Crónica de un conflicto normativo anunciado y análisis jurisprudencial", en Estudios Penales y Criminológicos, Vol. XXXIV, 2014, pág. 249 y ss.

Milıtello, "I nuovi modelli di incriminazione delle organizzacioni criminali all'interno dell'Unione Europea", cit., págs. 19-20.

Militello, V., "Profili penali e problema politico-criminali dell'intervento multilivello sugli stupefacenti. Un confronto fra Italia, Spagna e Unione Europea", en Rivista Trimestrale di Diritto penale dell'economia, № 1, 2014, pág. 95.

Miııtello, V., “Criminalidad organizada transnacional y Unión Europea”, texto hallado en la red, págs. 5 y 6.

Mapelul / González / Aguado (Coords.), Estudios sobre delincuencia organizada. Medios, instrumentos y estrategias de investigación policial, Sevilla, Mercablum, 2001, pág. 83.

Mıııtello, "L'identità della scienza giuridica penale nell'ordinamento multilivello", cit.,págs. 103-104.

Mercado, P., “El proceso de globalización, el Estado y el Derecho, Portilla (Dir.), Mutaciones del Leviatan. Legitimación de los nuevos modelos penales, Madrid, Akal, 2005, pág. 155.

Mıııtello, V., “L'identità della scienza giuridica penale nell'ordinamento multilivello", en Rivista italiana di Diritto e procedure penale, Fascículo 1, 2014, pág. 116. Messutı, Un deber ineludible, cit., pág. 196.

Miııtello, V., “I nuovi modelli di incriminazione delle organizzacioni criminali all'interno 
dell'Unione Europea", en AA. VV., Scritti in onore di Alfonso M. Stile, Nápoles, Editoriali Scientici, 2013, págs. 5-14.

LLeRENA, P., "La criminalidad organizada transnacional y finanzas", en la red, pág. 1. Quien cita la ponencia de Alfredo Nunzi, "The Elaboration of the United Nations Convention against Transnational Organized Crime", presentado por ISISC en el XVI Congreso Internacional de Derecho Penal, Budapest, Hungría, septiembre de 1999.

Pérez Luño, A., El desbordamiento de las fuentes del Derecho, Madrid, La Ley, 2011, pág. 96.

Parlamento Europeo, Working document on organized crime, Special committee on organized crime, corruption and money laundering, Relator Salvatore lacolino, DT/913961, en doc, 2009-2014, pág. 12.

Parlamento Europeo, Working document on organized crime, cit., pág. 3.

Pérez Cepeda, A., "Principio de justicia universal versus principio de jurisdicción universal", en de la misma, El principio de justicia universal: fundamento y límites, ob. cit., págs. 64-65.

Rosı, "La legge n. 146 del 16 marzo 2006 sul crimine organizzato transnazionale", cit., pág. 8.

Rosı, E., "La legge n. 146 del 16 marzo 2006 sul crimine organizzato transnazionale. In particolare, gli aspetti problematici della definizione di reato transnazionale. Aspetti problematici della definizione di reato transnazionale", en http://www.immigrazione.biz/upload/legge _ n_ 146_del_16_marzo_2006 sul_crimine_organizzato_transnazionale.pdf pág. 2.

Sartori, G., "Comparación y método comparativo", en Sartori/Morlino, La comparación en ciencias sociales, Madrid, Alianza Editorial, 2002, 1ª reimpresión, pág. 33.

Vogel J., en Revista Penal, No 11, 2003, "Política criminal y dogmática penal europeas", ob. cit., pág. 141

Velasco NúÑEz, E., "Crimen organizado: organización y grupo criminal tras la reforma del Código Penal en la L0 5/ 2010", cit., pág. 10.

Woodiwiss, M., "Transnational organized crime. The global reach of an American concept", en Edwards /Gill, Transnational Organized Crime. Perspectives on global security, Nueva York / Oxon, Routledge, 2003, pág. 15.

WerLE, G., Tratado de derecho penal internacional, Valencia, Tirant lo Blanch, 2005, pág. 95. 
ZúÑIga RodrígueZ, L., "Viejas y nuevas tendencias políticocriminales en las legislaciones actuales", en Berdugo Gómez de la Torre / Sanz Mulas, Derecho Penal de la democracia vs. Seguridad pública, Granada, Comares, 2005, passim, especialmente págs. 125-129.

Zúñiga Rodríguez, Criminalidad organizada y sistema del Derecho Penal. Contribución a la determinación del injusto penal de organización criminal, Granada, Comares, 2009, págs. 249 y ss.

Zagrebelsky, G. El Derecho dúctil. Ley, derechos, justicia, Madrid, Trotta, 2011, 10a ed, págs. $10-12$. 